Article

\title{
Cross-Linking and Evaluation of the Thermo-Mechanical Behavior of Epoxy Based Poly(ionic Liquid) Thermosets
}

\author{
Florian Wanghofer, Archim Wolfberger*(D), Markus Wolfahrt (D) and Sandra Schlögl (iD \\ Polymer Competence Center Leoben GmbH, Roseggerstraße 12, 8700 Leoben, Austria; \\ florian.wanghofer@pccl.at (F.W.); markus.wolfahrt@pccl.at (M.W.); sandra.schloegl@pccl.at (S.S.) \\ * Correspondence: archim.wolfberger@pccl.at
}

check for updates

Citation: Wanghofer, F.; Wolfberger,

A.; Wolfahrt, M.; Schlögl, S.

Cross-Linking and Evaluation of the

Thermo-Mechanical Behavior of

Epoxy Based Poly(ionic Liquid)

Thermosets. Polymers 2021, 13, 3914

https://doi.org/10.3390/polym13223914

Academic Editors

Łukasz Klapiszewski and

Beata Podkościelna

Received: 22 September 2021

Accepted: 8 November 2021

Published: 12 November 2021

Publisher's Note: MDPI stays neutral with regard to jurisdictional claims in published maps and institutional affiliations.

Copyright: (c) 2021 by the authors. Licensee MDPI, Basel, Switzerland. This article is an open access article distributed under the terms and conditions of the Creative Commons Attribution (CC BY) license (https:// creativecommons.org/licenses/by/ $4.0 /)$

\begin{abstract}
Poly(ionic liquids) (PILs) and ionenes are polymers containing ionic groups in their repeating units. The unique properties of these polymers render them as interesting candidates for a variety of applications, such as gas separation membranes and polyelectrolytes. Due to the vast number of possible structures, numerous synthesis protocols to produce monomers with different functional groups for task-specific PILs are reported in literature. A difunctional epoxy-IL resin was synthesized and cured with multifunctional amine and anhydride hardeners and the thermal and thermomechanical properties of the networks were assessed via differential scanning calorimetry and dynamic mechanical analysis. By the selection of suitable hardeners, the glass transition onset temperature $\left(T_{\mathrm{g} \text {,onset }}\right)$ of the resulting networks was varied between $18{ }^{\circ} \mathrm{C}$ and $99{ }^{\circ} \mathrm{C}$. Copolymerization of epoxy-IL with diglycidyl ether of bisphenol A (DGEBA) led to a further increase of the $T_{\mathrm{g} \text {,onset. }}$ The results demonstrate the potential of epoxy chemistry for tailorable PIL networks, where the hardener takes the place of the ligands without requiring an additional synthesis step and can be chosen from a broad range of commercially available compounds.
\end{abstract}

Keywords: ionic liquid; epoxy; ionene; poly(ionic liquid); thermoset

\section{Introduction}

Ionic liquids (ILs), which are generally defined as salts with melting points below $100{ }^{\circ} \mathrm{C}$, have attracted increased attention in recent years in research and industry [1-3]. They consist of a bulky organic cation and an organic or inorganic anion [4,5], decreasing the packing density of the molecules and reducing the melting temperature $\left(T_{\mathrm{m}}\right)$ compared to conventional inorganic salts [6,7]. Asymmetrical cations and weaker interactions between the ions usually shift the transition temperatures to lower values [8], in many cases even well below room temperature (RT) [9].

The unique properties of ILs, such as low flammability, negligible vapor pressure, moisture resistance, high thermal stability [10], reusability [11], ion conductivity [12], as well as catalytic activity [13-15], combined with their high tunability and wide range of available ILs with a vast number of possible anion-cation combinations give rise to many possible applications [10]. Examples are their use as solvents [16], latent curing agents [17], phase transfer catalysts [18], dispersing agents [19], and porogens [20,21], as well as their application in materials for $\mathrm{CO}_{2}$ capture [22], magneto-rheological fluids [23], and selfassembly of polymers [24]. Other reports include the formation of ionogels produced from ionic liquids and a suitable gelator, exhibiting high ionic conductivity and tunable properties that can be used as quasi-solid electrolytes $[25,26]$.

A further advantageous property of ILs is that they can also be functionalized with a variety of different reactive groups to act as non-volatile monomers for the realization of poly(ionic liquids) (PILs). Depending on their structure and position of the ionic moieties in the polymer chains, different terms are used to describe the resulting materials. An overview of the chemical structure of different poly(ionic liquids) is provided in Figure 1. The properties of the resulting PILs are greatly influenced by their respective ion pairs. 
Differences in the glass transition temperature $\left(T_{\mathrm{g}}\right)$ of $50{ }^{\circ} \mathrm{C}$ or more were reported for PILs by exchanging the respective counter-ions of the poly(ionic liquids) $[27,28]$. Thus, the properties of soluble PILs can be further tuned by anion exchange, even after polymerization [28-30]. Exchanging the anion can also be utilized to adjust the solubility of the polymer [31,32] and the mechanical properties [33]. Depending on the monomer structure and the ion pair, PILs can be designed to be hydrophobic [34,35], antibacterial [36], and non-flammable [37] polymers. While the anion selection offers many opportunities to create task specific materials, some anions result in a significant increase in brittleness and the PILs cannot be processed as a consequence [38-40].

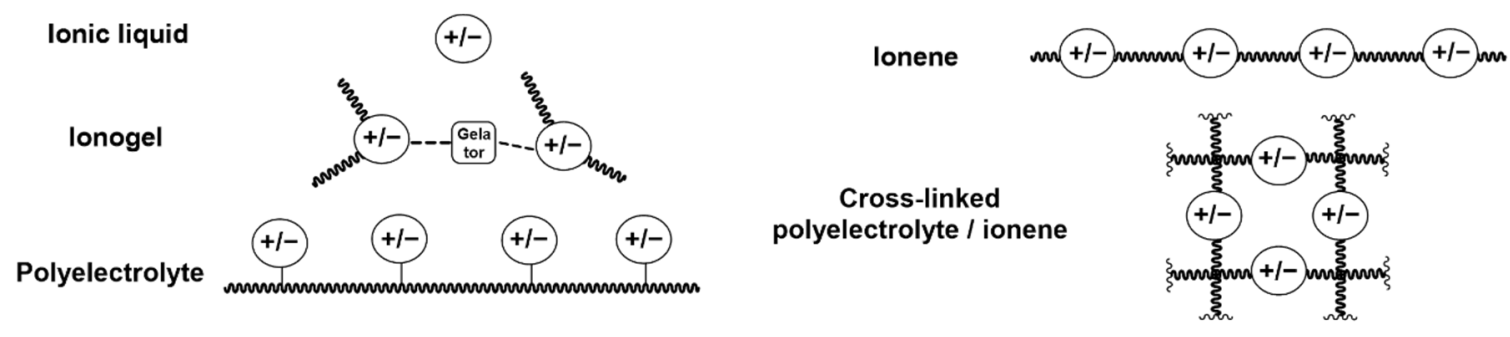

Figure 1. Schematic representation of different poly(ionic liquid) (PIL) structures and terminology thereof.

In many cases, PILs exhibit high $\mathrm{CO}_{2}$ solubility and solubility selectivity [41,42], especially in combination with free ionic liquids as solid-liquid composites [42-44]. This renders them very interesting candidates for gas separation membranes. The reported loadings of free ILs in the PIL membranes are often above $40 \mathrm{wt} . \%$ [45,46], whereas the PIL matrix increases the maximum filler capacity by intermolecular bonding and prevents leakage [28]. Moreover, PILs have shown to be potential candidates as catalysts for solvent free reactions $[47,48]$. Another interesting property of PILs is their ionic conductivity for applications as polyelectrolytes [49].

Several different approaches to polymerizing ILs have been reported in literature: (i) As pendant group of a polymerizable monomer [50,51], (ii) block copolymers of IL monomers with non-ionic monomers [52,53], (iii) by protonation of amine functional groups and subsequent cross-linking with an epoxy resin [54], (iv) or by using cross-linkable ionic liquid monomers [46]. While polymerizable cations are more common, it is also possible to functionalize the anion or even both ions $[55,56]$. The majority of the reported PILs are obtained from monomers with only one polymerizable group with the ionic moieties as pendant groups [57-59]. By polymerizing these monomers, a polyelectrolyte is formed.

Similar structures can be produced by grafting an ionic group to the backbone as a side chain [57,60-62] or via polymerization of a dihalide with bisimidazole molecules [63-66]. The latter results in ionenes, which are polymers with ionic moieties in their backbone [67]. PILs and ionenes are generally very similar and share the same field of applications [68]. However, while PILs are often based on mono-functional alkenyl moieties, and therefore, possess an aliphatic, non-ionic backbone, literature reports on ionenes increasingly focus on the introduction of ionic groups in high performance polymers such as polyimides $[63,69]$ or aromatic polyamides [64,70]. Furthermore, the position of the ions influences the ion aggregation [71] and an increased ion conductivity was found for ionenes in comparison to a polyelectrolyte [72].

IL-based ionenes can also be obtained from multifunctional ILs [73]. Difunctional ILs equipped with epoxy-functional groups (epoxy-IL) represent a very versatile class of materials. The oxirane ring exhibits reactivity towards a multitude of species and can be used for polymerization with amines, phenols, thiols, isocyanates or carboxylic acids following a step-growth mechanism. However, epoxies can also be polymerized by a chain-growth reaction mechanism, either as homopolymerisation or as alternating copolymerization with anhydrides [74,75]. Epoxy based polymers with thermoplastic properties can be produced by the homopolymerisation of monofunctional epoxy resins or by curing a difunctional epoxy resin with a difunctional hardener [76]. If the epoxy 
resin or the hardener have a functionality of more than two, cross-linked PILs/ionenes are acquired.

Most reported epoxy functional ILs are based on imidazolium cations, due to their high thermal stability [77], combined with bis(trifluoromethane)sulfonimide $\left(\mathrm{Tf}_{2} \mathrm{~N}^{-}\right)$anions, which ensure that even the large aromatic monomer molecules are liquid at lower temperatures [78], and yield hydrophobic polymers [34,36,79]. In contrast, epoxies based on the widely used diglycidyl ether of bisphenol A (DGEBA) tend to be more hydrophilic [34,80]. The starting compounds are usually functionalized using halides or tosylates, either by direct epoxidation with epichlorohydrin/epibromohydrin [81-85] or by addition of an alkenyl group and subsequent oxidation of the double bond $[42,46,49,78]$.

Table 1 summarizes literature examples of epoxy-IL monomers and their respective glass transition temperature after polymerization. McDanel et al. [42,46] synthesized PILs $1 \mathrm{~A}-\mathrm{D}$ for $\mathrm{CO}_{2}$ capture. The networks were produced by curing the respective monomers with tri- or hexa-functional amine hardeners. Through variation of the hardeners and their stoichiometry, the authors were able to significantly influence the $\mathrm{CO}_{2}$ uptake of the materials as well as the respective glass transition temperatures.

Radchenko et al. [34] synthesized the aromatic PIL 2 that can be used for shape memory applications due to its two relaxation temperatures at $60{ }^{\circ} \mathrm{C}$ and $109{ }^{\circ} \mathrm{C}$. The authors reported comparably high mechanical properties, with a Young's modulus of $1.63 \mathrm{GPa}$, a yield strength of $96 \mathrm{MPa}, 28 \%$ strain at break as well as a storage modulus of $1.7 \mathrm{GPa}$ at room temperature. In another publication, the authors produced the three monomer materials $3 \mathrm{~A}-\mathrm{C}$, which have a high potential for 3D-printing applications in combination with diaryliodonium hexafluoroantimonate as the UV or thermally activated initiator. The cationically cured monomer 3B led to a polymeric network with a storage modulus of $1.18 \mathrm{GPa}$ [86].

Livi et al. [36,49] produced PILs from monomers 4A-C for antibacterial coatings or surfaces and reported a biofilm inhibition of more than $80 \%$ for all three polymers. The PILs exhibited rather high glass transition temperatures between $53{ }^{\circ} \mathrm{C}$ and $62{ }^{\circ} \mathrm{C}$, considering that an aliphatic hardener was used. The highest value was reported for $4 \mathrm{~B}$, which does not contain an ether bond in the epoxy monomer. The storage moduli are similar for all three polymers, with $700 \mathrm{MPa}$ reported for $4 \mathrm{~A}$ at room temperature $[36,49]$. Apart from a reduced stiffness of PILs compared to commercially available epoxy monomers, the ionic character is expected to have an influence on the reactivity of functional groups. While the peak of the exotherm of $4 \mathrm{~A}$ during curing is observed at lower temperatures than that of DGEBA [49], it is less reactive than monomer $4 \mathrm{C}$ with its two aromatic ligands. The authors attribute this lower reactivity to the higher distance of the oxirane ring to the cation [36]. The substituents do not only influence the properties of the monomer but also the synthesis. Electron donating groups on aromatic rings reduce the reaction speed during the oxidation of the alkenyl group to yield epoxide rings. The highest effect was observed for ester groups in the synthesis of various monomers [78]. 
Table 1. Overview of PILs based on epoxy functional imidazolium ionic liquids reported in literature.

(1D) (1B)

(3A) $\quad n=2$

(3B) $n=1$

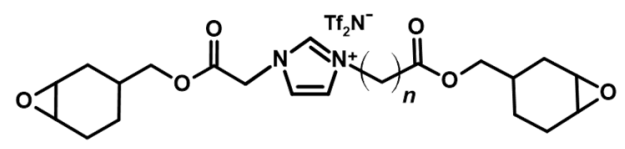

(3C)

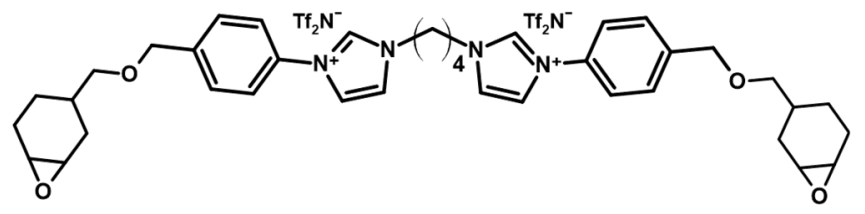

(4A) $\mathrm{R}=-\mathrm{O}-\mathrm{CH}_{2}-$

(4B)<smiles>C[N+](C)CCC1CO1</smiles>

(4C)<smiles></smiles><smiles>CC(N)COCC(C)N</smiles>
Curing Agent
(5)<smiles>c1c[n+](CC2CO2)cn1CC1CO1</smiles><smiles>Nc1cccc(Oc2cccc(Oc3cccc(N)c3)c2)c1</smiles>

Curing Agent

$\mathrm{Tf}_{2} \mathrm{~N}^{-}=$Bis(trifluoromethane)sulfonimide.

Grugel and co-workers [79] investigated the properties of epoxy-IL resins in detail to examine their suitability as matrix materials in carbon fiber reinforced composites for the storage of liquid hydrogen and for cryogenic applications. The thermoset resulting from curing of monomer 5 is reported to exhibit low flammability, hydrogen permeability and thermal expansion, as well as increased adhesion, lap shear and tensile strength. Increased impact resistance and fracture toughness were observed, especially under cryogenic conditions in comparison to a commercially available DGEBA based epoxy resin. The reported tensile strength of approximately $60 \mathrm{MPa}$ is significantly lower than for PIL 2 but still within the range of technical resins [79]. It has to be noted that the IL was cross-linked with an aromatic amine hardener, while the reference DGEBA resin was cured with polyoxypropylenetriamine, an aliphatic polyether. PIL 5 was exposed to aging tests in space, facing earth for approx. 2 years, in which it went through 12,500 cycles between $-40^{\circ} \mathrm{C}$ to $40{ }^{\circ} \mathrm{C}$ under 
the influence of radiation and oxygen. The investigated specimen on aluminum substrates exhibited no cracks, delamination or loss of adhesion after the tests [87]. Furthermore, the material was tested with fiber reinforcements and exhibited increased strain under liquid nitrogen conditions and better adhesion to the fibers compared to a common DGEBA based thermoset. A different crack growth behavior was observed for DGEBA based thermosets and PIL 5. The DGEBA based material exhibited failure along the interface between fiber and epoxy, while the crack propagated through the epoxy matrix for PIL 5 and even plastic deformation before failure was reported [88]. In contrast, PIL 5 did not show any cracks or delamination from temperature cycles between cryogenic and room temperature, and surpassed commercial systems in terms of tensile and bond strength [89].

Another possibility to synthesize IL based epoxy networks is to functionalize the cation with a group that can react with epoxy monomers, such as amines or carboxyl groups. Amine functional ILs can also be obtained by quaternization of an amine curing agent [54], by exchanging the anion to an amino acid, which allows the synthesis of ILs with both functional anions and cations [22,90]. Another route involves the Radziszewski imidazole synthesis using functionalized amines, which is reported for the production of both amine and carboxylic acid functional ILs [91,92].

Jiang et al. [93] synthesized diamine imidazolium hardeners with dicyanamide and $\mathrm{Tf}_{2} \mathrm{~N}^{-}$anions and used it to cure a trifunctional epoxy resin. The authors determined the ideal amount of hardener to be $15 \mathrm{wt}$.\% of IL, which is non-stoichiometric. Therefore, a significant number of cross-links can be expected to be based on homopolymerisation, which is likely the reason for the higher glass transition temperature $\left(212^{\circ} \mathrm{C} / 196{ }^{\circ} \mathrm{C}\right)$ of the network compared to other reported PILs. Apart from a high $T_{\mathrm{g}}$, the thermoset exhibited good mechanical properties with a tensile strength of up to $40 \mathrm{MPa}$ and a strong influence of the anion. Using $\mathrm{Tf}_{2} \mathrm{~N}^{-}$as counterion resulted in a lower cross-link density and tensile modulus but increased tensile strength and elongation at break. Interestingly, despite the decreased cross-link density, a higher $T_{\mathrm{g}}$ were reported for the $\mathrm{Tf}_{2} \mathrm{~N}^{-}$anion than for the dicyanamide.

Jin et al. [60] reported a seven-fold increase of impact strength upon the addition of a carboxyl functional polyether with pending imidazolium IL groups to a commercial epoxy resin. It has to be noted that the addition of the polyether also introduces long alkyl chains into the network, which might play a significant role in the impact strength enhancement.

Apart from epoxy groups, amines can also react with anhydrides to form polyimides. Li, Zhang et al. [73,94,95] produced random and block-copolyimides with mono- and di-cationic amine ILs. The addition of different ratios of the amine IL led to an increase in density while it significantly decreased the molecular weight and the glass transition temperature from initial $296^{\circ} \mathrm{C}$ to as low as $177^{\circ} \mathrm{C}$ for $30 \mathrm{~mol} \%$ of IL.

Due to this high tunability and sheer endless combinations, numerous reports on the synthesis and characterization of task-specific PILs are available in literature. This, in turn, requires custom syntheses for most PILs. Livi and co-workers simulated the properties of homopolymerized epoxy PILs based on the monomer structure to reduce the amount of different syntheses required [96]. In the present work, the versatility and considerable potential of epoxy-functional ILs is further demonstrated via the selection and implementation of different hardeners, resulting in an effective tailoring of the properties of the prepared epoxy-IL networks. Specific focus is laid on a systematic evaluation of the thermal and thermo-mechanical properties of representative epoxy-IL networks, cured with different types of hardeners. For this purpose, an epoxy-functional IL monomer with comparably short side-chains was synthesized and cured with selected multifunctional amine hardeners. The thermal and thermo-mechanical properties of the resulting epoxyIL networks are examined and compared to a reference DGEBA based epoxy resin as a benchmark. To the best of the authors' knowledge, this has not been extensively done so far. The potential for a flexible tailoring of the network properties of epoxy-IL resins is further demonstrated by an investigation of resin systems prepared with varying mixing ratios between epoxy-functional IL and DGEBA as a commonly used benchmark resin. 


\section{Materials and Methods}

\subsection{Chemicals and Materials}

$1 H$-imidazole, 3-chloroperoxybenzoic acid (77\%), 3-(aminomethyl)-3,5,5-trimethylcyclohexanamine (IPD), 4,4'-diaminodiphenylsulfone (DDS), and trimethyl-1,6-hexanediamine (TMHMDA) were obtained from Sigma-Aldrich (St. Louis, MO, USA). 4-bromo-1-butene and lithium bis(trifluoromethane)sulfonimide were purchased from ABCR (Karlsruhe, Germany). 4-methyl-hexahydro-phthalic anhydride (MHHPA) and bisphenol A diglycidyl ether (DGEBA) were supplied by Huntsman (The Woodlands, TX, USA). N,Ndimethylbenzylamine (BDMA) was purchased from Fisher Scientific (Hampton, NH, USA). All chemicals were used without further purification.

\subsection{Synthesis and Thermal Curing of Ionic Liquids}

1,3-bis(2-oxiranyl-ethyl)imidazolium $\mathrm{Tf}_{2} \mathrm{~N}^{-}$(IL-E) was synthesized according to a procedure published by McDanel et al. [46]. $20.07 \mathrm{~g}$ Imidazole (294 mmol) was dissolved in $170 \mathrm{~mL}$ acetonitrile and $24.8 \mathrm{~g} \mathrm{NaHCO} 3(294 \mathrm{mmol})$ and $83.57 \mathrm{~g}$ 4-bromo-1-butene $(617 \mathrm{mmol})$ were added to the solution and refluxed for $15 \mathrm{~h}$. The reaction mixture was allowed to cool to room temperature, subsequently filtered and the solvent was removed under reduced pressure. $175 \mathrm{~mL}$ of de-ionized water were added to the residue, followed by washing with ethyl acetate and heptane. An amount of $88.83 \mathrm{~g}(309 \mathrm{mmol})$ of lithium bis(trifluoromethane)sulfonimide was added to the aqueous phase and the solution was stirred for $4 \mathrm{~h}$ at room temperature. The aqueous phase was separated, and the remaining oily layer was extracted with $500 \mathrm{~mL}$ ethyl acetate. The organic phase was washed with $1 \mathrm{M}$ aqueous $\mathrm{HCl}$ solution and saturated $\mathrm{NaHCO}_{3}$ solution, followed by washes with de-ionized water until the test with $\mathrm{AgNO}_{3}$ was negative for halides. $\mathrm{MgSO}_{4}$ and activated charcoal was afterwards added to the organic phase. After stirring for $3 \mathrm{~h}$, the solution was filtered through basic alumina and the solvent was removed under reduced pressure to yield $122 \mathrm{~g}$ (90\% yield) of 1,3-di(3-butenyl)imidazolium $\mathrm{Tf}_{2} \mathrm{~N}$. The epoxidation was performed batchwise: $45 \mathrm{~g}$ (98 mmol) 1,3-di(3-butenyl)imidazolium Tf2N was dissolved in $200 \mathrm{~mL}$ acetonitrile, $90 \mathrm{~g}$ (394 mmol) 3-chloroperoxybenzoic acid was added and the solution was then stirred for $48 \mathrm{~h}$ at room temperature. The reaction mixture was filtered, and the solvent was removed under reduced pressure. Residual 3-chlorobenzoic acid and unreacted 3-chloroperoxybenzoic acid was removed by washing with 2-methoxy-2-methylpropan. The product was dried under vacuum to yield $35 \mathrm{~g}$ (73\%) of IL-E. The chemical structure was confirmed via ${ }^{1} \mathrm{H}$ - and ${ }^{13} \mathrm{C}-\mathrm{NMR}$ in DMSO-d6, and FTIR spectroscopy using literature reports $[46,97,98]$ (Figures S1-S3, Supplementary Materials).

IL-E was cured with selected amine and anhydride hardeners in stoichiometric ratios. TMHMDA, IPD, and DDS were used in a molar ratio of 0.5 to the epoxy resin. MHHPA was added in a molar ratio of 1.7 to IL-E, with $3 \mathrm{wt} . \%$ BDMA in relation to the epoxy resin as accelerator. DGEBA was cured with DDS in a molar ratio of 1:0.5 as a reference thermoset. For the production of resin containing both IL-E and DGEBA, the resins were mixed in the desired molar ratios prior to the addition of DDS in a stoichiometric ratio. Liquid hardeners were thoroughly mixed into the resin at room temperature. DDS was dissolved in the epoxy monomers by stirring the components at $150^{\circ} \mathrm{C}$ until a homogenous mixture was achieved (between 5 and $20 \mathrm{~min}$ ). The formulations were then homogenized in a vortex mixer and degassed under vacuum before curing. An overview of the chemical structure of the implemented resins and hardeners, their respective abbreviation and cure conditions of the networks is listed in Table 2. 
Table 2. Overview of the composition of the prepared epoxy-based resins and their respective cure cycles.

IL-TMHMDA

\subsection{Characterization Methods}

Infrared spectra were recorded on a Vertex 70 spectrometer (Bruker, Billerica, MA, USA) in attenuated total reflectance (ATR) mode with the software OPUS 7.5 (Bruker, Billerica, MA, USA). A total number of 16 scans were gathered from $500 \mathrm{~cm}^{-1}$ to $4500 \mathrm{~cm}^{-1}$ with a resolution of $2 \mathrm{~cm}^{-1}$.

Measurements of the viscosity of the investigated resins were done using an MCR 501 rheometer (Anton Paar, Graz, Austria). The plate-plate measurements were conducted with a shear rate of $10 \mathrm{~s}^{-1}$ and a deformation of $7 \%$ at $30^{\circ} \mathrm{C}$.

A dynamic mechanical analysis (DMA) was done on a DMA/SDTA861 $1^{\mathrm{e}}$ instrument (Mettler-Toledo, Columbus, OH, USA) in tensile mode with a clamping length of $9 \mathrm{~mm}$ in accordance to DIN EN ISO 6721-4 [99]. Rectangular specimens of $20 \mathrm{~mm} \times 2.5 \mathrm{~mm} \times 1 \mathrm{~mm}$ were tested in a temperature range of $50{ }^{\circ} \mathrm{C}$ up to a maximum temperature of $250{ }^{\circ} \mathrm{C}$ or at least $100^{\circ} \mathrm{C}$ above the maximum tan delta with a heating rate of $2 \mathrm{~K} / \mathrm{min}$ under nitrogen. All measurements were performed in the strain-controlled mode with $3 \mu \mathrm{m}$ deformation, $1 \mathrm{~Hz}$ frequency and $150 \%$ off-set.

The thermal analysis equipment DSC 4000 (PerkinElmer, Waltham, MA, USA) was used for differential scanning calorimetry (DSC) measurements according to DIN EN ISO $11357-2$ [100]. The weight of the samples in the standard aluminium pans $(40 \mu \mathrm{L})$ was in the range of $12 \mathrm{mg}$ to $14 \mathrm{mg}$ for cured samples and $4 \mathrm{mg}$ to $6 \mathrm{mg}$ for uncured samples. All samples were first heated from $-50{ }^{\circ} \mathrm{C}$ to $200{ }^{\circ} \mathrm{C}$ or $300{ }^{\circ} \mathrm{C}$, for resins containing DDS, with $20 \mathrm{~K} / \mathrm{min}$ under nitrogen atmosphere. Afterwards, each sample was cooled 
down to $-50^{\circ} \mathrm{C}$. In the subsequent second run, all samples were heated up again to the above-mentioned temperatures using the same heating rate and atmosphere. The glass transition temperature was determined as midpoint temperature in accordance to the relevant standard using the software Pyris (PerkinElmer, Waltham, MA, USA).

${ }^{1} \mathrm{H}-\mathrm{NMR}$ and ${ }^{13} \mathrm{C}$-NMR spectra were recorded on a Bruker (Billerica, MA, USA) Advance III $300 \mathrm{MHz}$ NMR spectrometer in DMSO-d6.

Thermogravimetric analysis (TGA) was performed on a TGA/DSC thermogravimetric analyser (Mettler-Toledo, Columbus, OH, USA) from $25^{\circ} \mathrm{C}$ to $900^{\circ} \mathrm{C}$ with a heating rate of $10 \mathrm{~K} / \mathrm{min}$ under nitrogen in aluminium oxide crucibles with a volume of $70 \mu \mathrm{l}$ and an approximate sample weight of $30 \mathrm{mg}$. The measured curves were evaluated with the STAR $^{\mathrm{e}}$ Evaluation Software (Mettler-Toledo, Columbus, OH, USA)

Density was measured in distilled water using a $50 \mathrm{~mL}$ pycnometer with a ground-in thermometer at room temperature. The density of the samples $\rho_{s}$ was calculated from the sample weight $m_{s}$, the weight of the pycnometer filled with water $m_{w}$, the weight of the pycnometer filled with water and the sample $m_{s w}$, and the density of water at the respective temperature $\rho_{w}$ using the following equation:

$$
\rho_{s}=\frac{m_{s}}{m_{s}+m_{w}-m_{s w}} * \rho_{w}
$$

\section{Results and Discussion}

The synthesis of the ionic liquid 1,3-bis(2-oxiranyl-ethyl)imidazolium trifluoromethanesulfonimide (IL-E) via alkenylation followed by ion exchange and epoxidation [46] proved to be a very robust and efficient procedure for the production of epoxy-ILs with high purity, as also indicated by the obtained NMR spectra and the nearly colorless appearance of the IL [101]. The monomer was chosen for this study due to its chemical structure with comparably short side chains. This allows for more versatility, since the network properties can be effectively tailored and repeating units between the ionic moieties can be easily varied by the hardener. IL-E exhibits a viscosity of $150 \mathrm{mPa}$ s at $30^{\circ} \mathrm{C}$ and was stable during storage for several months. In comparison, a significantly higher viscosity of $860 \mathrm{mPa} s$ was measured for the commonly used epoxy resin DGEBA.

\subsection{Thermal Properties of Thermally Cured IL-E}

The epoxy-IL resins were thermally cured with aliphatic, cycloaliphatic and aromatic amine hardeners to achieve cross-linked networks with different chemical and physical properties. Their curing behavior was monitored via DSC and complete curing was characterized during the second heating run. Due to the higher reactivity of the systems including aliphatic and cycloaliphatic amines (IL-TMHMDA and IL-IPD), curing already started at room temperature after mixing the materials and the compositions could therefore not be stored for extended periods of time. The systems with the aromatic DDS hardener (IL-DDS) presented a higher latency. IL-DDS was stored in a fridge for several weeks and no pronounced phase separation or curing reaction was observed, which is in good agreement with the longer pot life and gel time of aromatic hardeners compared to aliphatic hardeners reported in literature [102,103]. The anhydride system (IL-MHHPA) also showed a starting curing reaction but can nonetheless be stored over extended periods (at least one week) of time if no accelerator is added. Typical DSC scans for the various epoxy-IL resins are depicted in Figure 2. Table 3 summarizes the characteristic temperatures of the uncured resin-hardener mixtures. The glass transition temperature, midpoint temperature in the second heating run of DSC tests, is denoted as $T_{\mathrm{g}, \mathrm{u}}$. The results confirm the initial observation of the latency of IL-DDS having significantly higher temperatures of the exothermic peak ( $T_{\text {peak }}$ ) of $283^{\circ} \mathrm{C}$ and curing onset ( $T_{\text {onset }}$ ) of $171^{\circ} \mathrm{C}$ than the other epoxyIL systems. A slightly smaller exothermic peak was observed at $230^{\circ} \mathrm{C}$. In consideration of the relatively low $T_{g, u}$ of $65^{\circ} \mathrm{C}$ for IL-DDS, the secondary exotherm was assigned to epoxy-IL homopolymerisation reactions. When comparing IL-DDS with DGEB-DDS, it can be seen that $T_{\text {onset }}$ of $185^{\circ} \mathrm{C}$ and $T_{\text {peak }}$ of $238^{\circ} \mathrm{C}$ for DGEB-DDS correspond very well 
with $T_{\text {onset }}$ and the first exotherm of IL-DDS. This further indicates that the higher $T_{\text {peak }}$ is derived from etherification [104]. It has to be noted that at such high temperatures some thermal degradation is likely to occur and a slight exotherm is visible when heating the pure IL-E to $300{ }^{\circ} \mathrm{C}$ in the DSC, however, no peak was visible. Epoxy-anhydride systems generally require a catalyst such as tertiary amines to initiate the alternating ring-opening polymerization and the onset temperature can be influenced by the variation of the catalyst concentration [105]. With $3 \mathrm{wt} . \%$ BDMA as catalyst, a curing onset of $120^{\circ} \mathrm{C}$ and $T_{\text {peak }}$ of $161{ }^{\circ} \mathrm{C}$ was measured for IL-MHHPA. Attempts to reduce the curing temperature for IL-DDS by addition of $1 \mathrm{wt} . \%$ BDMA resulted in a significant reduction of $T_{\text {onset }}$ and $T_{\text {peak }}$ to $88{ }^{\circ} \mathrm{C}$ and $135{ }^{\circ} \mathrm{C}$, respectively. However, using the accelerator also resulted in a drastically reduced $T_{\mathrm{g}, \mathrm{u}}$ value of $38^{\circ} \mathrm{C}$, indicating that BDMA mainly initiated the homopolymerisation of the IL, and was therefore disregarded. This observation is in good agreement with reports on catalyzed DGEB-DDS systems [106].

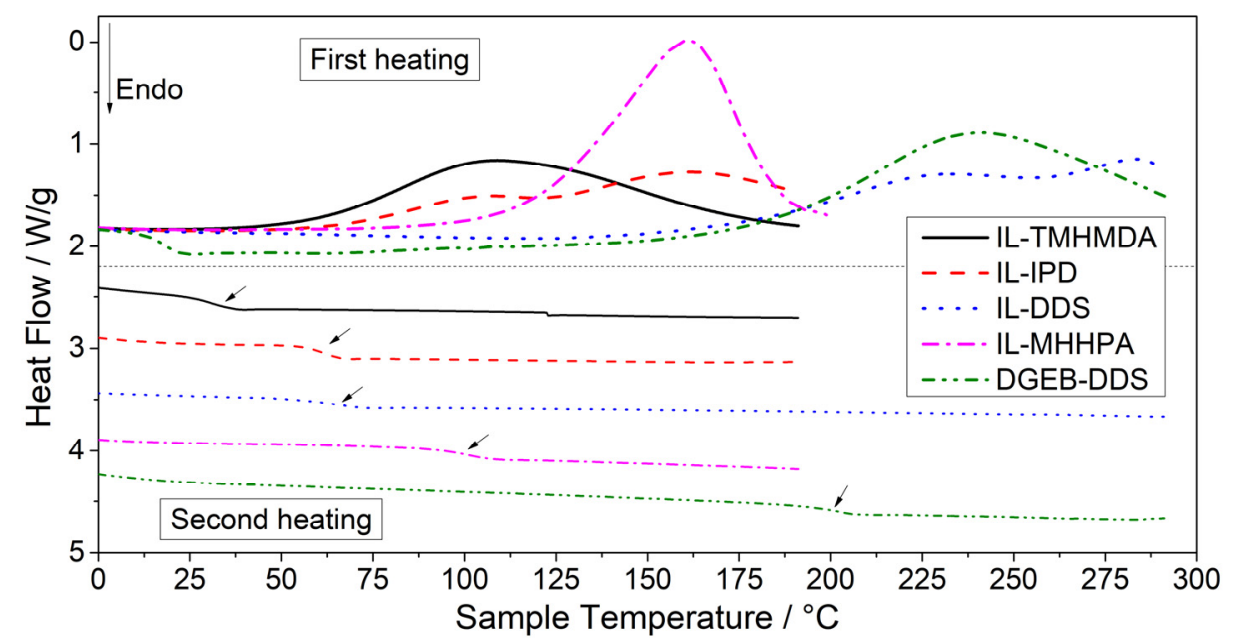

Figure 2. DSC thermograms of the uncured resin-hardener mixtures, including the first (top) and second (bottom) heating. Curves shifted vertically for better visibility.

Table 3. Characteristic temperatures obtained from DSC measurements performed on the uncured systems: $T_{\mathrm{onset}}$ and $T_{\text {peak }}$ of the curing reaction (first heating), and glass transition temperature $\left(T_{\mathrm{g}, \mathrm{u}}\right)$ (second heating).

\begin{tabular}{cccc}
\hline Resin/Hardener & $\boldsymbol{T}_{\text {onset }},{ }^{\circ} \mathbf{C}$ & $T_{\text {peak }},{ }^{\circ} \mathbf{C}$ & $\boldsymbol{T}_{\mathbf{g}, \mathbf{u}},{ }^{\circ} \mathbf{C}$ \\
\hline IL-TMHMDA & 58 & 109 & 32 \\
\hline IL-IPD & 63 & $108 \& 161$ & 61 \\
\hline IL-DDS & 171 & $230 \& 283$ & 65 \\
\hline IL-MHHPA & 120 & 161 & 99 \\
\hline DGEB-DDS & 177 & 241 & 200 \\
\hline
\end{tabular}

IL-IPD also exhibited a double exotherm at $108{ }^{\circ} \mathrm{C}$ and $161^{\circ} \mathrm{C}$. In this case, the double exotherm can be attributed to the different reactivity of the aliphatic and cycloaliphatic amine groups of the non-symmetrical IPD hardener [107]. This is further evidenced when comparing IL-IPD with IL-MHHPA and IL-TMHDA, cured with cycloaliphatic and aliphatic hardeners, respectively. The higher $T_{\text {peak }}$ is at the same temperature as for IL-MHHPA. On the other hand, the $T_{\text {onset }}$ of $63{ }^{\circ} \mathrm{C}$ and the lower $T_{\text {peak }}$ at $108{ }^{\circ} \mathrm{C}$ are very similar to IL-TMHMDA, with a $T_{\text {onset }}$ of $58^{\circ} \mathrm{C}$ and a $T_{\text {peak }}$ at $109^{\circ} \mathrm{C}$. The use of the aliphatic hardener in IL-TMHMDA also resulted in the lowest $T_{\mathrm{g}, \mathrm{u}}$ of $32^{\circ} \mathrm{C}$. Apart from DGEB-DDS with $200^{\circ} \mathrm{C}$, the anhydride system IL-MHHPA exhibited the highest $T_{\mathrm{g}, \mathrm{u}}$ of $99^{\circ} \mathrm{C}$, being even higher than the epoxy-IL system including the DDS hardener with its 
high aromatic content. IL-IPD with its mixed structure exhibits a $T_{\mathrm{g}, \mathrm{u}}$ of $63{ }^{\circ} \mathrm{C}$, ranking it between IL-TMHMDA and IL-MHHPA.

\section{DSC Measurements of Cured Samples}

For a further investigation of the thermal properties, additional samples were prepared by resin casting and subsequent curing in a convection oven according to the determined temperature profiles for full curing. The curing temperatures were chosen in consideration of the respective $T_{\text {onset }}$ and $T_{\text {peak }}$ (see Table 3 ). Although the uncured resin samples did not exhibit an exothermic peak after the first heating run in DSC tests, a prolonged curing (post-curing) in the oven allowed to reach a higher glass transition temperature $\left(T_{g, c}\right)$ for the amine-cured systems. After reaching the gel-point, the curing reactions changes from kinetics-controlled to diffusion-controlled [108]. The additional curing time allows the diffusion-controlled curing process to proceed to a higher conversion, leading to a higher cross-link density and thus, higher $T_{\mathrm{g}}$. Figure 3 includes a comparison of the second heating curve from DSC tests with the compositions after post-curing to visualize the shift from $T_{\mathrm{g}, \mathrm{u}}$ to $T_{\mathrm{g}, \mathrm{c}}$. After post-curing, the glass transition temperature $\left(T_{\mathrm{g}, \mathrm{c}}\right)$ of IL-TMHMDA was increased by $8{ }^{\circ} \mathrm{C}$ to $39^{\circ} \mathrm{C}$ and by $4{ }^{\circ} \mathrm{C}$ to $65^{\circ} \mathrm{C}$ for IL-IPD, respectively. The discrepancy between $T_{\mathrm{g}, \mathrm{u}}$ and $T_{\mathrm{g}, \mathrm{c}}$ is especially pronounced for IL-DDS and a $T_{\mathrm{g}, \mathrm{c}}$ of $97^{\circ} \mathrm{C}$ compared to the $T_{\mathrm{g}, \mathrm{u}}$ of $65^{\circ} \mathrm{C}$ was reached. Interestingly, the IL-DDS system still exhibits a $T_{\mathrm{g}}$ of more than $100{ }^{\circ} \mathrm{C}$ lower compared to the respective DGEB-DDS system with a $T_{g, c}$ of $220^{\circ} \mathrm{C}$. Compared to literature values of DGEBA cured with IPD with up to $155^{\circ} \mathrm{C}$ [109], a similar relation can be observed for the $T_{\mathrm{g}, \mathrm{c}}$ of IL-IPD at $64{ }^{\circ} \mathrm{C}$. The anhydride cured system IL-MHHPA reached nearly $70 \%$ of reported values for DGEBA cured with MHHPA [110]. It is expected that this originates from the different molar and consequently weight ratios of the anhydride system. While the molar ratio of IL-E to DDS or IPD is 2:1, it is 1:1.7 for IL-MHHPA. Therefore, the final network properties are more significantly determined by the hardener structure for the anhydride system. Concluding from these results, the characteristic temperatures $\left(T_{\mathrm{g}, \mathrm{c}}, T_{\text {peak }}\right.$ and $\left.T_{\mathrm{g}, \mathrm{u}}\right)$ decrease in the order aromatic $>$ cycloaliphatic $>$ aliphatic for the amine curing agents, while the anhydride hardener provides a $T_{\mathrm{g}}$ comparable to the aromatic amine hardener (see Figure 3 ), which follows the same trend as conventional epoxy systems [110,111].

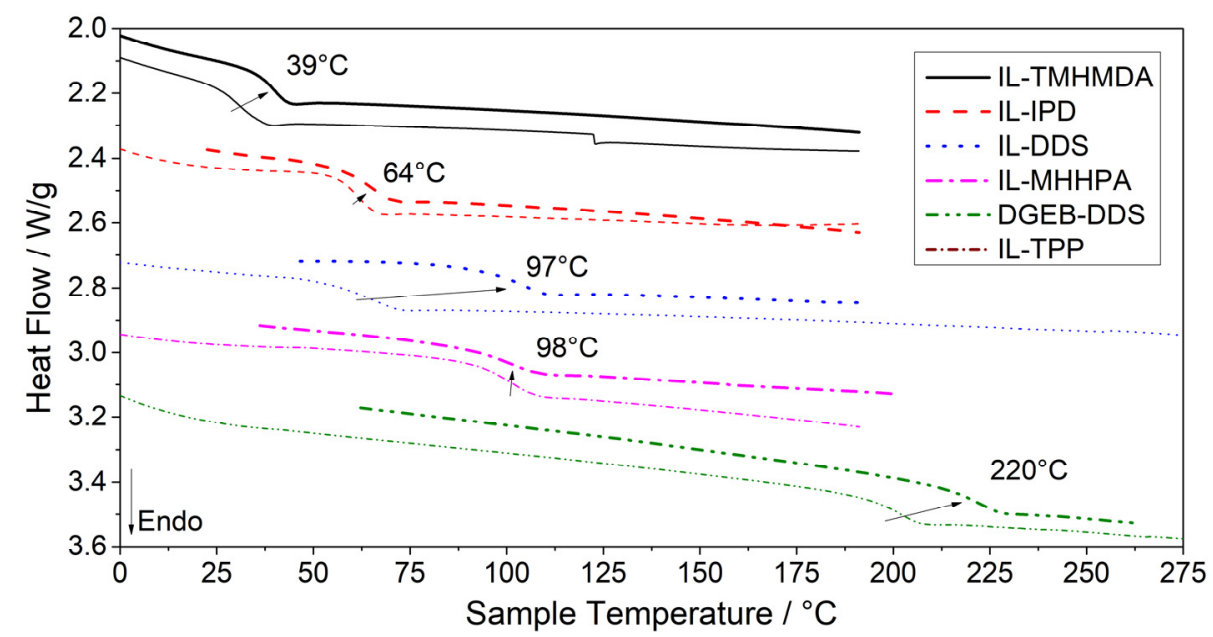

Figure 3. Shift of glass transition temperatures by prolonged post-curing (thick lines) compared to the second heating of uncured resins (thin lines) as determined in DSC. Curves shifted vertically for better visibility. 
TGA measurements (Figure 4) were done on fully cured epoxy-IL resins and DGEBDDS systems in order to determine the thermal stability of the cured systems. The results are in good agreement with the high thermal stability of imidazolium based ionic liquids reported in literature [112]. The highest degradation temperature at $5 \%$ mass loss $\left(T_{\mathrm{dec}, 5}\right)$ was determined for DGEB-DDS at $385^{\circ} \mathrm{C}$. This high stability is explained by the highly aromatic content of the resin-hardener system. For the epoxy-IL samples, a two-step degradation is visible. The initial mass loss can be assigned to the degradation of the aliphatic moieties, initiated by the cleavage of the $\mathrm{N}-\mathrm{C}$ bonds to the quaternized imidazolium nitrogen atoms. This is undermined by the significantly lower initial weight loss for the pristine, uncured IL-E and by the degradation of DGEB-DDS. The aromatic hardener DDS slightly increases the thermal stability of the cured IL-DDS network to a $T_{\text {dec }, 5}$ of $334{ }^{\circ} \mathrm{C}$, above the stability of the pristine IL-E $\left(T_{\mathrm{dec}, 5}=321^{\circ} \mathrm{C}\right)$. The cycloaliphatic hardener IPD, however, does not improve the thermal stability and is comparable to the linear aliphatic hardener TMHMDA, with $T_{\text {dec, }, 5}$ of $300{ }^{\circ} \mathrm{C}$ and $301{ }^{\circ} \mathrm{C}$ for IL-IPD and IL-TMHMDA, respectively. A $T_{\text {dec, },}$ of $338^{\circ} \mathrm{C}$ was measured for IL-MHHPA, indicating that the aliphatic amine of IPD might be the determining factor for the thermal stability.

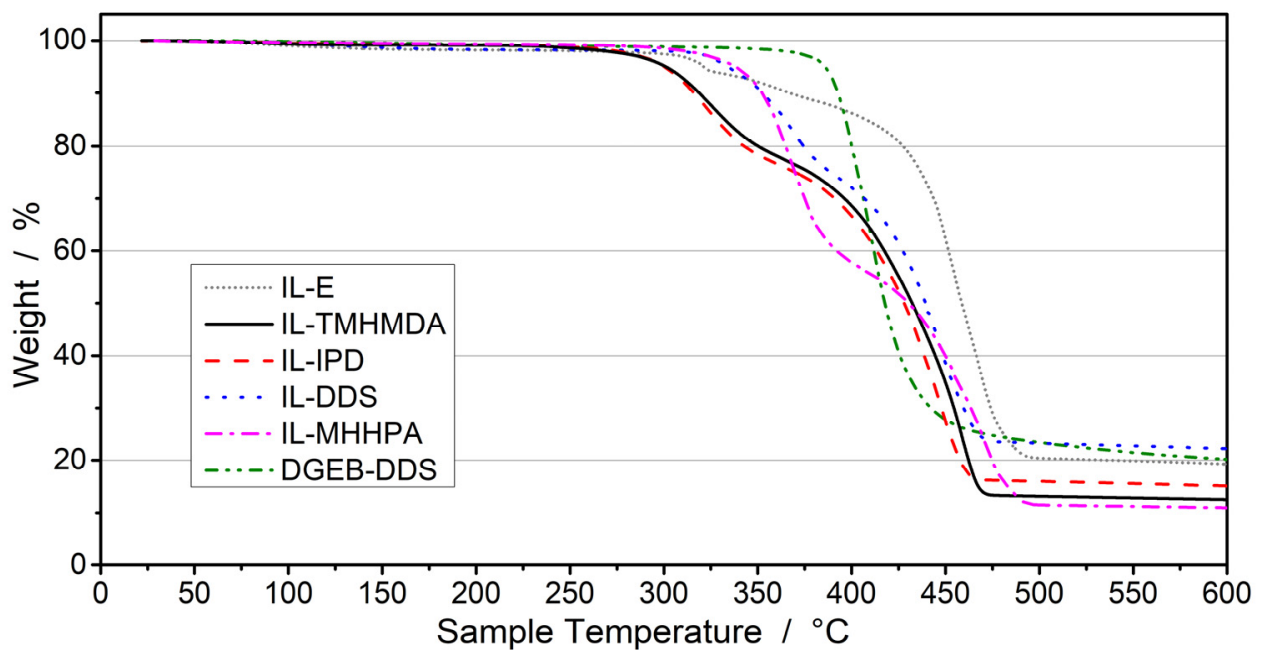

Figure 4. TGA curves obtained for IL-E and fully cured epoxy/hardener compositions.

\subsection{Thermomechanical Properties of Thermally Cured IL-E}

Dynamic mechanical analysis (DMA) was performed on cured specimens prepared by resin casting in order to characterize the temperature dependence of the mechanical properties and to estimate the stiffness of the materials. Storage modulus $\left(E^{\prime}\right)$ and glass transition temperature values as determined from these tests are shown in Table 4.

Table 4. Glass transition temperatures and storage moduli obtained from DMA.

\begin{tabular}{|c|c|c|c|c|}
\hline \multirow{2}{*}{ Material } & \multicolumn{2}{|c|}{$T_{\mathrm{g}},{ }^{\circ} \mathrm{C}$} & \multirow{2}{*}{$\begin{array}{c}E^{\prime}, \mathrm{GPa} \\
T=0{ }^{\circ} \mathrm{C}\end{array}$} & \multirow{2}{*}{$E_{\mathrm{r}^{*}}^{\prime}, \mathrm{Mpa}$} \\
\hline & Onset & $\operatorname{Max} \tan \delta$ & & \\
\hline IL-TMHMDA & 18 & 28 & 1.3 & 7.8 \\
\hline IL-IPD & 44 & 73 & 2.2 & 7.0 \\
\hline IL-MHHPA & 91 & 107 & 1.9 & 10.0 \\
\hline IL-DDS & 99 & 113 & 2.1 & 9.8 \\
\hline DGEB-DDS & 196 & 220 & 2.2 & 33 \\
\hline
\end{tabular}

${ }^{*} E_{\mathrm{r}}^{\prime}$ : Storage modulus in rubbery state $\left(T=T(\max \tan \delta)+30^{\circ} \mathrm{C}\right)$. 
Curing of IL-TMHMDA led to comparably soft networks with a $T_{\mathrm{g}}$ of $28^{\circ} \mathrm{C}$ and a storage modulus ( $\left.E^{\prime}\right)$ of $1.3 \mathrm{GPa}$. This behavior accounts for the lack of aromatic moieties between imidazolium groups, allowing for a higher chain mobility and decreasing the stiffness of the polymer backbone [113]. McDanel et al. [46] reported a similar $T_{\mathrm{g}}$ of $38^{\circ} \mathrm{C}$ for the IL-E monomer cured with a triamine. However, the authors calculated a conversion of only $67 \%$. An excess amount of hardener increased the conversion to $80 \%$ but at the same time reduced the $T_{\mathrm{g}}$ to $9^{\circ} \mathrm{C}$ due to the introduction of further aliphatic groups.

The implementation of the cycloaliphatic hardener in the IL-IPD resin system led to an increase of the $T_{\mathrm{g}}$ to $73^{\circ} \mathrm{C}$. Due to its high aromatic character, the IL-DDS system shows a further increase of the $T_{\mathrm{g}}$ to $113^{\circ} \mathrm{C}$. As discussed in the previous section, the comparably high $T_{\mathrm{g}}$ of $107^{\circ} \mathrm{C}$ for the cured resin including the cycloaliphatic MHHPA hardener likely derives from the higher ratio of hardener to epoxy-IL resin. However, when compared to the DGEB-DDS system with a $T_{\mathrm{g}}$ of $220^{\circ} \mathrm{C}$, the glass transition of the epoxy-IL networks is still located at significantly lower temperatures. Apart from the different chemical structure of the heterocyclic imidazole, the increased volume due to the bulky anions implemented in the epoxy-IL networks and their plasticizing effect is expected to be the major influence on the decreased $T_{\mathrm{g}}$. While the $\mathrm{Tf}_{2} \mathrm{~N}^{-}$anion provides many desirable properties e.g., in terms of viscosity of the monomer and thermal stability, if further increase of the $T_{\mathrm{g}}$ is required, an anion exchange to reduce the free volume might be reasonable.

The non-symmetrical hardener IPD leads to a cured epoxy-IL network with a slightly broader glass transition and nearly $30^{\circ} \mathrm{C}$ difference between the onset temperature and the peak of $\tan \delta$. A secondary relaxation temperature, visible as a shoulder in the $\tan \delta$ curve (Figure 5), is observed for IL-IPD. This is accounted for by the chemical structure of IPD and the influence of the cycloaliphatic structure.

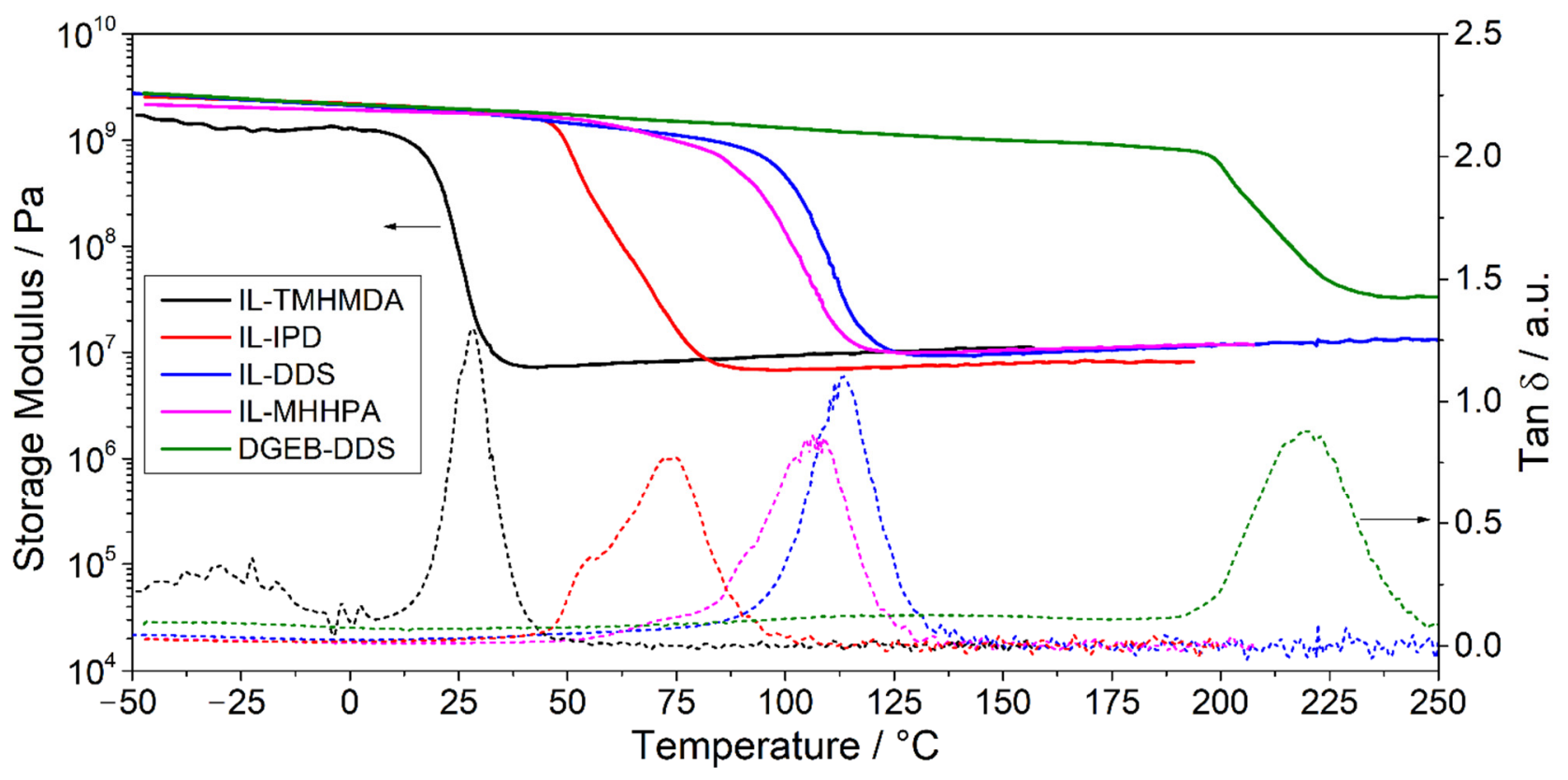

Figure 5. Storage modulus (solid lines) and $\tan \delta$ (dashed lines) of the PIL networks and DGEB-DDS. 
IL-IPD and IL-DDS exhibit storage moduli of $2.2 \mathrm{GPa}$ and $2.1 \mathrm{GPa}$ at $0{ }^{\circ} \mathrm{C}$, respectively, similar to DGEB-DDS with $2.2 \mathrm{GPa}$, due to the rigid cyclic groups introduced by the hardeners. Interestingly, the anhydride cured network shows a lower E' of $1.9 \mathrm{GPa}$ at $0{ }^{\circ} \mathrm{C}$, despite its high $T_{\mathrm{g}}$. At $31^{\circ} \mathrm{C}$, E' of IL-MHHPA intersects with that of IL-DDS. However, $\mathrm{E}^{\prime}$ of IL-MHHPA increases less significantly with decreasing temperature. At $-48^{\circ} \mathrm{C} \mathrm{E}^{\prime}$ amounts to $2.7 \mathrm{GPa}$ and $2.6 \mathrm{GPa}$ for IL-DDS and IL-IPD, respectively, while the modulus of IL-MHHPA only increased to $2.2 \mathrm{GPa}$. This indicates that the properties of the anhydride cured systems are less temperature dependent at low temperatures than the amine system, which might be advantageous for applications with large temperature differences.

Above the glass transition region, the epoxy-IL networks exhibit similar storage moduli in the rubbery state $\left(E_{r}^{\prime}\right)$ of $7.0 \mathrm{MPa}, 7.8 \mathrm{MPa}, 9.8 \mathrm{MPa}$, and $10.0 \mathrm{MPa}$, following the order IL-IPD < IL-TMHMDA < IL-DDS < IL-MHHPA, while a $E_{r}^{\prime}$ of $33 \mathrm{MPa}$ was measured for DGEB-DDS. This indicates that the IL-E determines the $E_{r}^{\prime}$ of the epoxy-IL networks and the effect of the hardener is less pronounced.

Further networks were prepared by adding DGEBA as co-monomer and compositions with molar ratios of 1:0, 1:1, 9:1, and 0:1 of IL-E/DGEBA were produced and cured with DDS. The influence of the DGEBA content on the thermo-mechanical properties of the cured PIL networks was studied. The aim of these experiments was to determine the influence of the DGEBA content on the thermo-mechanical properties of the resulting networks, since conventional DGEBA resins have been extensively investigated in the past and DGEBDDS networks provided good thermal stability and thermo-mechanical behavior in our experiments. Such blends of functionalized ionic liquids with other epoxy-based resins, which are not only limited to DGEBA, enable a high flexibility in tailoring the resulting network properties. In addition to the thermo-mechanical properties of the resulting epoxy-IL networks, also the ionic character and ion conductivity can therefore be flexibly tailored. Figure 6 depicts the DMA curves (a) as well as the glass transition temperatures and densities $(b)$ of the networks in dependence of the molar fractions of epoxy monomers. Both the glass transition temperature and the density are observed to change linearly with the mol fractions. With increasing amounts of the IL monomer, the glass transition temperature of the thermoset decreases from $220^{\circ} \mathrm{C}$ to $169{ }^{\circ} \mathrm{C}, 119{ }^{\circ} \mathrm{C}$ and $113^{\circ} \mathrm{C}$, while the density increases from $1.24 \mathrm{~g} / \mathrm{cm}^{3}$ to $1.41 \mathrm{~g} / \mathrm{cm}^{3}, 1.58 \mathrm{~g} / \mathrm{cm}^{3}$ and $1.63 \mathrm{~g} / \mathrm{cm}^{3}$ for $50 \mathrm{~mol} \%$, $90 \mathrm{~mol} \%$ and $100 \mathrm{~mol} \%$ IL-E, respectively. This is in accordance with findings of other reports where imidazolium $\operatorname{Tf}_{2} \mathrm{~N}$ derivatives were used as co-monomers [94,95]. The large $\mathrm{Tf}_{2} \mathrm{~N}^{-}$anion is reported to act as a plasticizer and leads to polymers with a low $T_{\mathrm{g}}$ [114]. The curing of DGEBA and epoxy-IL successfully yielded a homogenous network, as there are no additional relaxation temperatures visible and the glass transition range does not broaden. Therefore, while decreasing the ionic character of the material, the addition of DGEBA as co-monomer seems to be a suitable method to produce PILs for high thermomechanical demands. Compared to the copolyimides produced by Li et al. [73], the $T_{\mathrm{g}}$ is still significantly lower. However, the system is promising for lower $T_{\mathrm{g}}$ applications as the epoxy monomer is easier to process and does not require solvents, while higher IL loadings are achievable. 


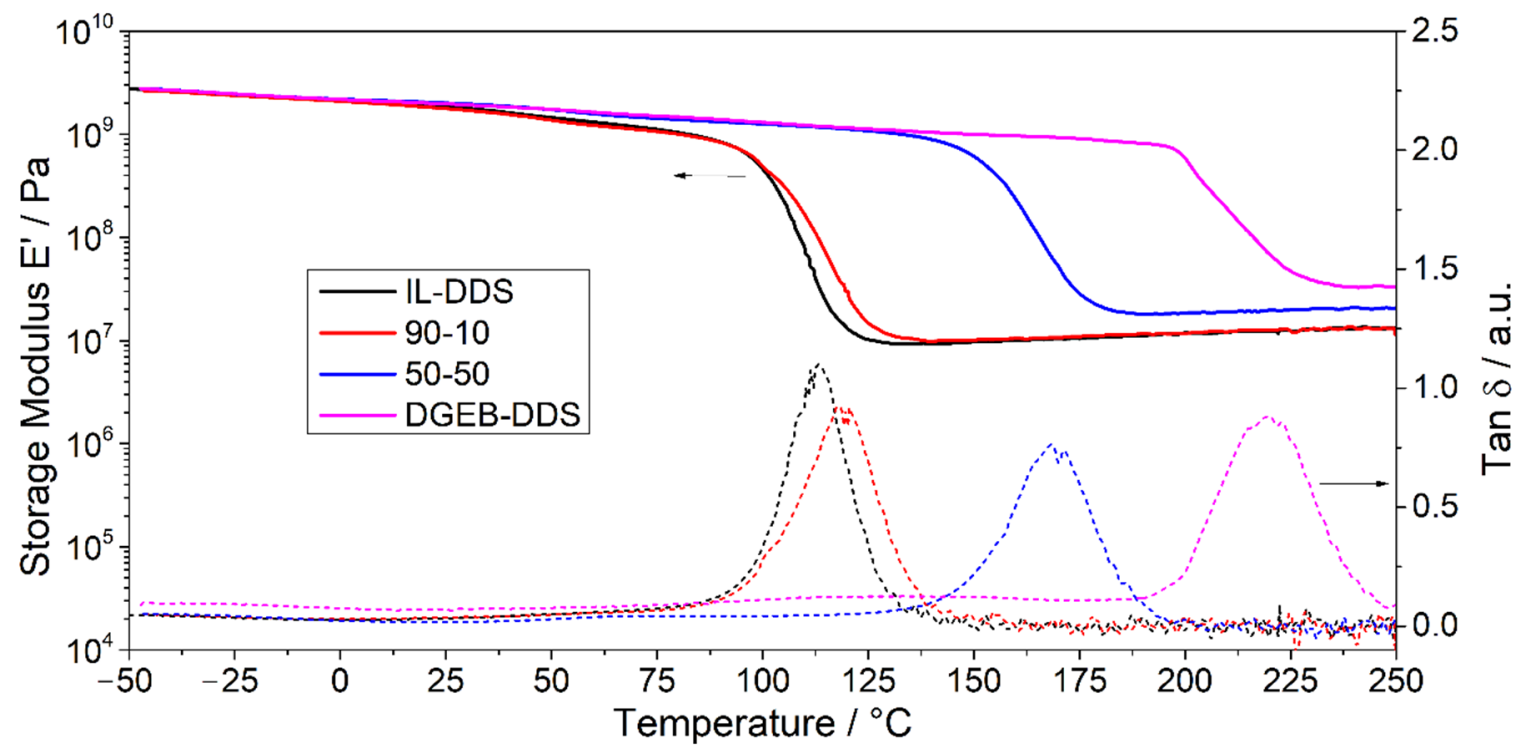

(a)

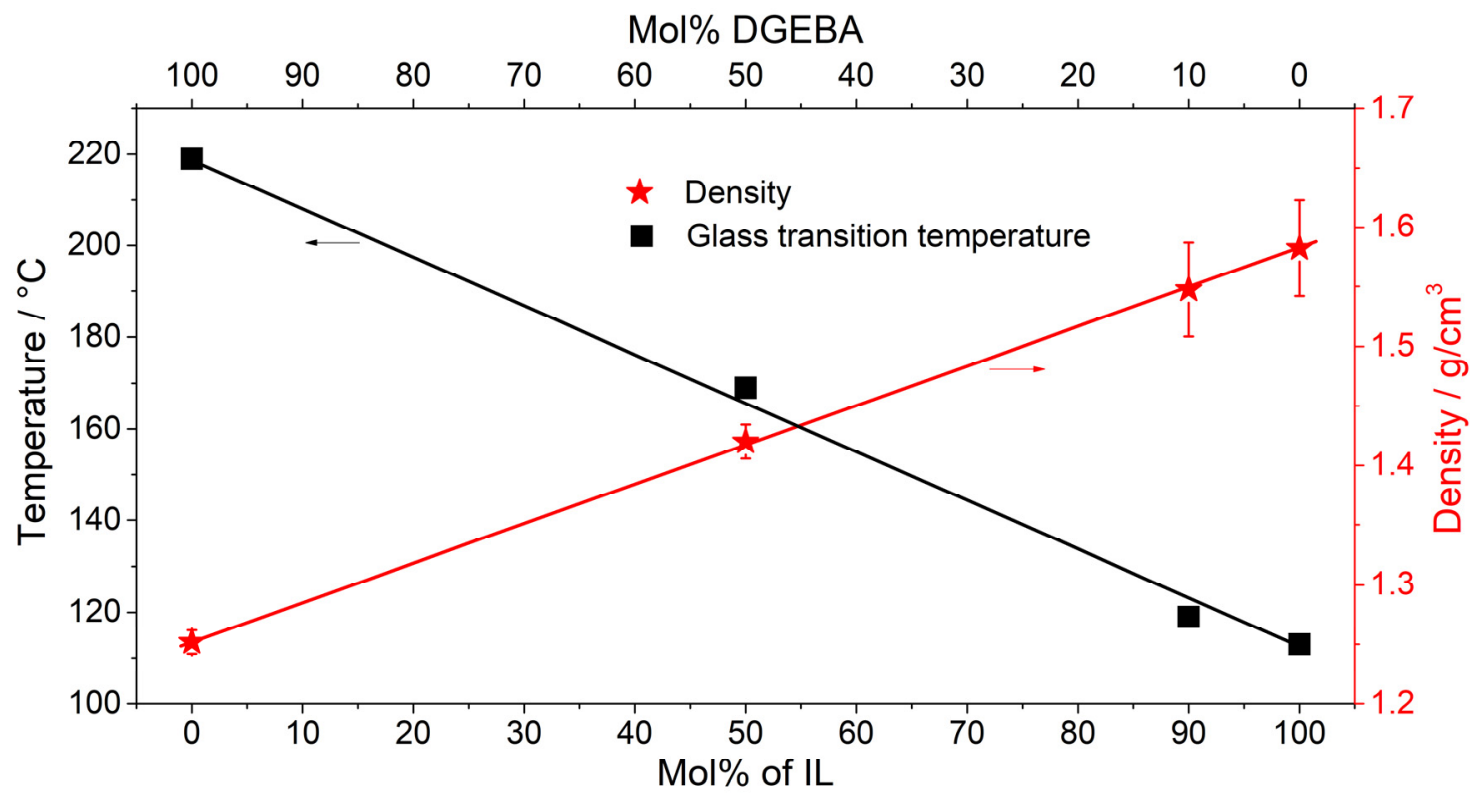

(b)

Figure 6. (a) Storage modulus (solid lines) and $\tan \delta$ (dashed lines) of the copolymers. (b) $T_{\mathrm{g}}(\mathbf{\square})$ and density ( $\star$ ) of the copolymers in dependence of the molar fractions of epoxy monomers.

\section{Conclusions}

In the present work, the versatility of epoxy functionalized ionic liquids to achieve cross-linked poly(ionic liquids) with tunable properties was demonstrated. An epoxy-IL network was synthesized and the thermal and thermo-mechanical properties as a function of the applied hardener were evaluated. Due to the vast commercial use of conventional epoxy systems and the reactivity of the oxirane rings towards a multitude of species, crosslinked IL-thermosets can be produced easily, and the properties can be tailored by using commercially available hardeners. This was illustrated by adjusting the glass transition temperature of epoxy-IL networks from $30{ }^{\circ} \mathrm{C}$ to $100{ }^{\circ} \mathrm{C}$ using four different hardeners. The $T_{\mathrm{g}}$ was shifted to even higher temperatures, by adding DGEBA to the formulations. All reported networks only required thorough mixing and thermal curing, without the need of any solvent, for the preparation of free-standing specimens. This demonstrates the 
potential of epoxy-IL monomers for multiple technical applications and the possibilities of effectively tailoring the resulting resin properties by a suitable selection of hardener and co-monomer. Further evaluation of suitable alternatives to the implemented $\mathrm{Tf}_{2} \mathrm{~N}^{-}$anion opens up possibilities for cost effective epoxy-IL based monomers and possibly higher resulting $T_{\mathrm{g}}$ values, including the beneficial properties of ionic liquid monomers for certain applications.

Supplementary Materials: The following are available online at https:/ /www.mdpi.com/article/ 10.3390/ polym13223914/s1, Figure S1: ${ }^{1}$ H-NMR spectrum of IL-E, Figure S2: 13C-NMR spectrum of IL-E, Figure S3: FTIR-spectrum of IL-E with corresponding characteristic frequency regions. References $[46,97,98]$.

Author Contributions: Conceptualization, A.W., M.W. and S.S.; methodology, F.W.; formal analysis, F.W.; investigation, F.W.; writing — original draft preparation, F.W., A.W., M.W. and S.S.; writingreview and editing, F.W., A.W., M.W. and S.S.; supervision, S.S.; project administration, M.W. and A.W.; funding acquisition, M.W. and S.S. All authors have read and agreed to the published version of the manuscript.

Funding: This research work was performed within the COMET-module "Polymers4Hydrogen" (project-no.: 21647053) at the Polymer Competence Center Leoben GmbH (PCCL, Austria) within the framework of the COMET-program of the Federal Ministry for Transport, Innovation and Technology and the Federal Ministry for Digital and Economic Affairs. PCCL is funded by the Austrian Government and the State Governments of Styria, Lower Austria and Upper Austria.

Institutional Review Board Statement: Not applicable.

Informed Consent Statement: Not applicable.

Data Availability Statement: The data presented in this study are available on request from the corresponding author.

Acknowledgments: The authors thank the involved partners Montanuniversitaet Leoben (Department Polymer Engineering and Science, Chair of Chemistry of Polymeric Materials, Chair of Materials Science and Testing of Polymers), Technical University of Munich (Department of Mechanical Engineering, Chair of Carbon Composites), Tampere University (Department of Engineering Material Science), Peak Technology and Faurecia for their contributions to this research work.

Conflicts of Interest: The authors declare no conflict of interest.

\section{References}

1. Zhao, Q.; Anderson, J.L. 2.11-Ionic Liquids. In Comprehensive Sampling and Sample Preparation: Analytical Techniques for Scientists; Pawliszyn, J., Ed.; Elsevier Academic Press: Amsterdam, The Netherlands, 2012; pp. 213-242. ISBN 978-0-12-381374-9.

2. Singh, S.K.; Savoy, A.W. Ionic liquids synthesis and applications: An overview. J. Mol. Liq. 2020, 297, 112038. [CrossRef]

3. Siriwardana, A.I. Industrial Applications of Ionic Liquids. In Electrochemistry in Ionic Liquids; Torriero, A.A.J., Ed.; Springer: Cham, Switzerland, 2015; pp. 563-603. ISBN 978-3-319-15131-1.

4. Izgorodina, E.I.; Forsyth, M.; MacFarlane, D.R. Towards a Better Understanding of 'Delocalized Charge' in Ionic Liquid Anions. Aust. J. Chem. 2007, 60, 15-20. [CrossRef]

5. Soares, B.G.; Livi, S.; Duchet-Rumeau, J.; Gerard, J.-F. Synthesis and Characterization of Epoxy/MCDEA Networks Modified with Imidazolium-Based Ionic Liquids. Macromol. Mater. Eng. 2011, 296, 826-834. [CrossRef]

6. Styring, P. Chapter 7-Novel Sorbent Materials for Carbon Capture. In Novel Materials for Carbon Dioxide Mitigation Technology; Morreale, B., Shi, F., Eds.; Elsevier: Amsterdam, The Netherlands, 2015; pp. 207-229. ISBN 978-0-444-63259-3.

7. Harada, L.; Pereira, J.; Campos, W.; Silva, E.; Moutinho, C.; Vila, M.; Oliveira, J., Jr.; Teixeira, J.; Balcão, V.; Tubino, M. Insights into Protein-Ionic Liquid Interactions Aiming at Macromolecule Delivery Systems. J. Braz. Chem. Soc. 2018. [CrossRef]

8. Walsh, D.A.; Goodwin, S. The Oxygen Reduction Reaction in Room-Temperature Ionic Liquids. In Encyclopedia of Interfacial Chemistry: Surface Science and Electrochemistry; Wandelt, K., Ed.; Elsevier: Amsterdam, The Netherlands; Oxford, UK; Cambridge, MA, USA, 2018; pp. 898-907. ISBN 978-0-12-809894-3.

9. Marsh, K.N.; Boxall, J.A.; Lichtenthaler, R. Room temperature ionic liquids and their mixtures-A review. Fluid Phase Equilibria 2004, 219, 93-98. [CrossRef]

10. Vashchuk, A.; Fainleib, A.M.; Starostenko, O.; Grande, D. Application of ionic liquids in thermosetting polymers: Epoxy and cyanate ester resins. Express Polym. Lett. 2018, 12, 898-917. [CrossRef]

11. Mai, N.L.; Ahn, K.; Koo, Y.-M. Methods for recovery of ionic liquids-A review. Process. Biochem. 2014, 49, 872-881. [CrossRef] 
12. Yusuf, S.N.F.; Yahya, R.; Arof, A.K. Ionic Liquid Enhancement of Polymer Electrolyte Conductivity and their Effects on the Performance of Electrochemical Devices. In Progress and Developments in Ionic Liquids; Handy, S., Ed.; InTech: Rijeka, Croatia, 2017; ISBN 978-953-51-2902-8.

13. Wang, Q.; Cai, X.; Liu, Y.; Xie, J.; Zhou, Y.; Wang, J. Pd nanoparticles encapsulated into mesoporous ionic copolymer: Efficient and recyclable catalyst for the oxidation of benzyl alcohol with $\mathrm{O}_{2}$ balloon in water. Appl. Catal. B Environ. 2016, 189, 242-251. [CrossRef]

14. Hou, W.; Wang, Q.; Guo, Z.; Li, J.; Zhou, Y.; Wang, J. Nanobelt $\alpha$-CuV $2 \mathrm{O} 6$ with hydrophilic mesoporous poly(ionic liquid): A binary catalyst for synthesis of 2,5-diformylfuran from fructose. Catal. Sci. Technol. 2017, 7, 1006-1016. [CrossRef]

15. Zhang, Z.; Hu, S.; Song, J.; Li, W.; Yang, G.; Han, B. Hydrogenation of $\mathrm{CO}_{2}$ to formic acid promoted by a diamine-functionalized ionic liquid. ChemSusChem 2009, 2, 234-238. [CrossRef] [PubMed]

16. Kubisa, P. Application of ionic liquids as solvents for polymerization processes. Prog. Polym. Sci. 2004, 29, 3-12. [CrossRef]

17. Nguyen, T.K.L. New Generation of Epoxy Networks Based on Ionic Liquids: From Structuration to Final Properties. Ph.D. Thesis, Université de Lyon, Lyon, France, 2019.

18. Kumar, V.; Jamie Talisman, I.; Bukhari, O.; Razzaghy, J.; Malhotra, S.V. Dual role of ionic liquids as phase transfer catalyst and solvent for glycosidation reactions. RSC Adv. 2011, 1, 1721-1727. [CrossRef]

19. Bugatti, V.; Viscusi, G.; Di Bartolomeo, A.; Iemmo, L.; Zampino, D.C.; Vittoria, V.; Gorrasi, G. Ionic Liquid as Dispersing Agent of LDH-Carbon Nanotubes into a Biodegradable Vinyl Alcohol Polymer. Polymers 2020, 12, 495. [CrossRef]

20. Booker, K.; Holdsworth, C.; Bowyer, M.; McCluskey, A. Ionic Liquids as Porogens in the Synthesis of Molecularly Imprinted Polymers. In Applications of Ionic Liquids in Science and Technology; Handy, S., Ed.; InTech: Rijeka, Croatia, 2011; ISBN 978-953-307-605-8.

21. Bai, L.; Wang, J.; Zhang, H.; Liu, S.; Qin, J.; Liu, H. Ionic liquid as porogen in the preparation of a polymer-based monolith for the separation of protein by high performance liquid chromatography. Anal. Methods 2015, 7, 607-613. [CrossRef]

22. Zhang, Y.; Zhang, S.; Lu, X.; Zhou, Q.; Fan, W.; Zhang, X. Dual amino-functionalised phosphonium ionic liquids for $\mathrm{CO}_{2}$ capture. Chemistry 2009, 15, 3003-3011. [CrossRef] [PubMed]

23. Guerrero-Sanchez, C.; Ortiz-Alvarado, A.; Schubert, U.S. Temperature effect on the magneto-rheological behavior of magnetite particles dispersed in an ionic liquid. J. Phys. Conf. Ser. 2009, 149, 12052. [CrossRef]

24. Guerrero-Sanchez, C.; Wouters, D.; Hoeppener, S.; Hoogenboom, R.; Schubert, U.S. Micellar dye shuttle between water and an ionic liquid. Soft Matter 2011, 7, 3827-3831. [CrossRef]

25. Ribot, J.C.; Guerrero-Sanchez, C.; Greaves, T.L.; Kennedy, D.F.; Hoogenboom, R.; Schubert, U.S. Amphiphilic oligoether-based ionic liquids as functional materials for thermoresponsive ion gels with tunable properties via aqueous gelation. Soft Matter 2012, 8, 1025-1032. [CrossRef]

26. Ribot, J.C.; Guerrero-Sanchez, C.; Hoogenboom, R.; Schubert, U.S. Thermoreversible ionogels with tunable properties via aqueous gelation of an amphiphilic quaternary ammonium oligoether-based ionic liquid. J. Mater. Chem. 2010, 20, 8279-8284. [CrossRef]

27. Shaplov, A.S.; Ponkratov, D.O.; Vlasov, P.S.; Lozinskaya, E.I.; Komarova, L.I.; Malyshkina, I.A.; Vidal, F.; Nguyen, G.T.M.; Armand, M.; Wandrey, C.; et al. Synthesis and properties of polymeric analogs of ionic liquids. Polym. Sci. Ser. B 2013, 55, 122-138. [CrossRef]

28. Tomé, L.C.; Isik, M.; Freire, C.S.R.; Mecerreyes, D.; Marrucho, I.M. Novel pyrrolidinium-based polymeric ionic liquids with cyano counter-anions: High performance membrane materials for post-combustion $\mathrm{CO}_{2}$ separation. J. Membr. Sci. 2015, 483, 155-165. [CrossRef]

29. Li, X.; Zhang, Z.; Li, S.; Yang, L.; Hirano, S.-i. Polymeric ionic liquid-plastic crystal composite electrolytes for lithium ion batteries. J. Power Sources 2016, 307, 678-683. [CrossRef]

30. Pont, A.-L.; Marcilla, R.; de Meatza, I.; Grande, H.; Mecerreyes, D. Pyrrolidinium-based polymeric ionic liquids as mechanically and electrochemically stable polymer electrolytes. J. Power Sources 2009, 188, 558-563. [CrossRef]

31. Marcilla, R.; Blazquez, J.A.; Fernandez, R.; Grande, H.; Pomposo, J.A.; Mecerreyes, D. Synthesis of Novel Polycations Using the Chemistry of Ionic Liquids. Macromol. Chem. Phys. 2005, 206, 299-304. [CrossRef]

32. Marcilla, R.; Alberto Blazquez, J.; Rodriguez, J.; Pomposo, J.A.; Mecerreyes, D. Tuning the solubility of polymerized ionic liquids by simple anion-exchange reactions. J. Polym. Sci. Part A Polym. Chem. 2004, 42, 208-212. [CrossRef]

33. Tomé, L.C.; Aboudzadeh, M.A.; Rebelo, L.P.N.; Freire, C.S.R.; Mecerreyes, D.; Marrucho, I.M. Polymeric ionic liquids with mixtures of counter-anions: A new straightforward strategy for designing pyrrolidinium-based $\mathrm{CO}_{2}$ separation membranes. $J$. Mater. Chem. A 2013, 1, 10403-10411. [CrossRef]

34. Radchenko, A.V.; Chabane, H.; Demir, B.; Searles, D.J.; Duchet-Rumeau, J.; Gérard, J.-F.; Baudoux, J.; Livi, S. New Epoxy Thermosets Derived from a Bisimidazolium Ionic Liquid Monomer: An Experimental and Modeling Investigation. ACS Sustain. Chem. Eng. 2020. [CrossRef]

35. Bhavsar, R.S.; Kumbharkar, S.C.; Rewar, A.S.; Kharul, U.K. Polybenzimidazole based film forming polymeric ionic liquids: Synthesis and effects of cation-anion variation on their physical properties. Polym. Chem. 2014, 5, 4083-4096. [CrossRef]

36. Livi, S.; Lins, L.C.; Capeletti, L.B.; Chardin, C.; Halawani, N.; Baudoux, J.; Cardoso, M.B. Antibacterial surface based on new epoxy-amine networks from ionic liquid monomers. Eur. Polym. J. 2019, 116, 56-64. [CrossRef]

37. Zhang, S.-Y.; Zhuang, Q.; Zhang, M.; Wang, H.; Gao, Z.; Sun, J.-K.; Yuan, J. Poly(ionic liquid) composites. Chem. Soc. Rev. 2020, 49, 1726-1755. [CrossRef] 
38. Hu, X.; Tang, J.; Blasig, A.; Shen, Y.; Radosz, M. $\mathrm{CO}_{2}$ permeability, diffusivity and solubility in polyethylene glycol-grafted polyionic membranes and their $\mathrm{CO}_{2}$ selectivity relative to methane and nitrogen. J. Membr. Sci. 2006, 281, 130-138. [CrossRef]

39. Bhavsar, R.S.; Kumbharkar, S.C.; Kharul, U.K. Polymeric ionic liquids (PILs): Effect of anion variation on their $\mathrm{CO}_{2}$ sorption. $J$. Membr. Sci. 2012, 389, 305-315. [CrossRef]

40. Kumbharkar, S.C.; Bhavsar, R.S.; Kharul, U.K. Film forming polymeric ionic liquids (PILs) based on polybenzimidazoles for $\mathrm{CO}_{2}$ separation. RSC Adv. 2014, 4, 4500-4503. [CrossRef]

41. Bara, J.E.; Lessmann, S.; Gabriel, C.J.; Hatakeyama, E.S.; Noble, R.D.; Gin, D.L. Synthesis and Performance of Polymerizable Room-Temperature Ionic Liquids as Gas Separation Membranes. Ind. Eng. Chem. Res. 2007, 46, 5397-5404. [CrossRef]

42. McDanel, W.M.; Cowan, M.G.; Barton, J.A.; Gin, D.L.; Noble, R.D. Effect of Monomer Structure on Curing Behavior, $\mathrm{CO}_{2}$ Solubility, and Gas Permeability of Ionic Liquid-Based Epoxy-Amine Resins and Ion-Gels. Ind. Eng. Chem. Res. 2015, 54, 4396-4406. [CrossRef]

43. Bara, J.E.; Gabriel, C.J.; Hatakeyama, E.S.; Carlisle, T.K.; Lessmann, S.; Noble, R.D.; Gin, D.L. Improving $\mathrm{CO}_{2}$ selectivity in polymerized room-temperature ionic liquid gas separation membranes through incorporation of polar substituents. J. Membr. Sci. 2008, 321, 3-7. [CrossRef]

44. Bara, J.E.; Hatakeyama, E.S.; Gin, D.L.; Noble, R.D. Improving $\mathrm{CO}_{2}$ permeability in polymerized room-temperature ionic liquid gas separation membranes through the formation of a solid composite with a room-temperature ionic liquid. Polym. Adv. Technol. 2008, 19, 1415-1420. [CrossRef]

45. Carlisle, T.K.; Nicodemus, G.D.; Gin, D.L.; Noble, R.D. $\mathrm{CO}_{2}$ /light gas separation performance of cross-linked poly(vinylimidazolium) gel membranes as a function of ionic liquid loading and cross-linker content. J. Membr. Sci. 2012, 397-398, 24-37. [CrossRef]

46. McDanel, W.M.; Cowan, M.G.; Carlisle, T.K.; Swanson, A.K.; Noble, R.D.; Gin, D.L. Cross-linked ionic resins and gels from epoxide-functionalized imidazolium ionic liquid monomers. Polymer 2014, 55, 3305-3313. [CrossRef]

47. Leng, Y.; Wang, J.; Jiang, P. Amino-containing cross-linked ionic copolymer-anchored heteropoly acid for solvent-free oxidation of benzyl alcohol with $\mathrm{H}_{2} \mathrm{O}_{2}$. Catal. Commun. 2012, 27, 101-104. [CrossRef]

48. Liu, G.; Hou, M.; Song, J.; Jiang, T.; Fan, H.; Zhang, Z.; Han, B. Immobilization of Pdnanoparticles with functional ionic liquid grafted onto cross-linked polymer for solvent-free Heck reaction. Green Chem. 2010, 12, 65-69. [CrossRef]

49. Livi, S.; Chardin, C.; Lins, L.C.; Halawani, N.; Pruvost, S.; Duchet-Rumeau, J.; Gérard, J.-F.; Baudoux, J. From Ionic Liquid Epoxy Monomer to Tunable Epoxy-Amine Network: Reaction Mechanism and Final Properties. ACS Sustain. Chem. Eng. 2019, 7, 3602-3613. [CrossRef]

50. Ohno, H.; Yoshizawa, M.; Ogihara, W. Development of new class of ion conductive polymers based on ionic liquids. Electrochim. Acta 2004, 50, 255-261. [CrossRef]

51. Green, M.D.; La Salas-de Cruz, D.; Ye, Y.; Layman, J.M.; Elabd, Y.A.; Winey, K.I.; Long, T.E. Alkyl-Substituted N-Vinylimidazolium Polymerized Ionic Liquids: Thermal Properties and Ionic Conductivities. Macromol. Chem. Phys. 2011, 212, 2522-2528. [CrossRef]

52. Gu, Y.; Lodge, T.P. Synthesis and Gas Separation Performance of Triblock Copolymer Ion Gels with a Polymerized Ionic Liquid Mid-Block. Macromolecules 2011, 44, 1732-1736. [CrossRef]

53. Williams, S.R.; La Salas-de Cruz, D.; Winey, K.I.; Long, T.E. Ionene segmented block copolymers containing imidazolium cations: Structure-property relationships as a function of hard segment content. Polymer 2010, 51, 1252-1257. [CrossRef]

54. Dai, Z.; Ansaloni, L.; Gin, D.L.; Noble, R.D.; Deng, L. Facile fabrication of $\mathrm{CO}_{2}$ separation membranes by cross-linking of poly(ethylene glycol) diglycidyl ether with a diamine and a polyamine-based ionic liquid. J. Membr. Sci. 2017, 523, 551-560. [CrossRef]

55. Kammakakam, I.; Bara, J.E.; Jackson, E.M. Dual Anion-Cation Crosslinked Poly(ionic liquid) Composite Membranes for Enhanced $\mathrm{CO}_{2}$ Separation. ACS Appl. Polym. Mater. 2020, 2, 5067-5076. [CrossRef]

56. Matsumoto, K.; Endo, T. Synthesis of networked polymers with lithium counter cations from a difunctional epoxide containing poly(ethylene glycol) and an epoxide monomer carrying a lithium sulfonate salt moiety. J. Polym. Sci. Part A Polym. Chem. 2010, 48, 3113-3118. [CrossRef]

57. Mecerreyes, D. Applications of Ionic Liquids in Polymer Science and Technology; Springer: Berlin/Heidelberg, Germany, 2015; ISBN 978-3-662-44902-8.

58. Shaplov, A.S.; Ponkratov, D.O.; Vlasov, P.S.; Lozinskaya, E.I.; Malyshkina, I.A.; Vidal, F.; Aubert, P.-H.; Armand, M.; Vygodskii, Y.S. Solid-state electrolytes based on ionic network polymers. Polym. Sci. Ser. B 2014, 56, 164-177. [CrossRef]

59. O'Harra, K.E.; Noll, D.M.; Kammakakam, I.; DeVriese, E.M.; Solis, G.; Jackson, E.M.; Bara, J.E. Designing Imidazolium Poly(amideamide) and Poly(amide-imide) Ionenes and Their Interactions with Mono- and Tris(imidazolium) Ionic Liquids. Polymers 2020, 12, 1254. [CrossRef] [PubMed]

60. Jin, X.C.; Guo, L.Y.; Deng, L.L.; Wu, H. Study on epoxy resin modified by polyether ionic liquid. IOP Conf. Ser. Mater. Sci. Eng. 2017, 213, 12037. [CrossRef]

61. Bernard, F.L.; Polesso, B.B.; Cobalchini, F.W.; Donato, A.J.; Seferin, M.; Ligabue, R.; Chaban, V.V.; do Nascimento, J.F.; Dalla Vecchia, F.; Einloft, S. $\mathrm{CO}_{2}$ capture: Tuning cation-anion interaction in urethane based poly(ionic liquids). Polymer 2016, 102, 199-208. [CrossRef]

62. Vlassi, E.; Pispas, S. Imidazolium Quaternized Polymers Based On Poly(Chloromethyl Styrene) and their Complexes with FBS Proteins and DNA. Macromol. Chem. Phys. 2015, 216, 1718-1728. [CrossRef] 
63. Dennis, G.P.; O’Harra, K.E.; Kammakakam, I.; Jones, T.A.; Mittenthal, M.S.; Flowers, B.S.; Tuan, Y.; Jackson, E.M.; Bara, J.E. 6FDA -containing polyimide-ionene + ionic liquid gas separation membranes. J. Appl. Polym. Sci. 2020, 58, 2664-2674. [CrossRef]

64. Kammakakam, I.; O’Harra, K.E.; Dennis, G.P.; Jackson, E.M.; Bara, J.E. Self-healing imidazolium-based ionene-polyamide membranes: An experimental study on physical and gas transport properties. Polym. Int. 2019, 68, 1123-1129. [CrossRef]

65. Bara, J.E.; O'Harra, K.E.; Durbin, M.M.; Dennis, G.P.; Jackson, E.M.; Thomas, B.; Odutola, J.A. Synthesis and Characterization of Ionene-Polyamide Materials as Candidates for New Gas Separation Membranes. MRS Adv. 2018, 3, 3091-3102. [CrossRef]

66. Carlisle, T.K.; Bara, J.E.; Lafrate, A.L.; Gin, D.L.; Noble, R.D. Main-chain imidazolium polymer membranes for $\mathrm{CO}_{2}$ separations: An initial study of a new ionic liquid-inspired platform. J. Membr. Sci. 2010, 359, 37-43. [CrossRef]

67. Hess, M.; Jones, R.G.; Kahovec, J.; Kitayama, T.; Kratochvíl, P.; Kubisa, P.; Mormann, W.; Stepto, R.F.T.; Tabak, D.; Vohlídal, J.; et al. Terminology of polymers containing ionizable or ionic groups and of polymers containing ions (IUPAC Recommendations 2006). Pure Appl. Chem. 2006, 78, 2067-2074. [CrossRef]

68. Bara, J.E.; O'Harra, K.E. Recent Advances in the Design of Ionenes: Toward Convergence with High-Performance Polymers. Macromol. Chem. Phys. 2019, 1900078. [CrossRef]

69. O'Harra, K.E.; Kammakakam, I.; DeVriese, E.M.; Noll, D.M.; Bara, J.E.; Jackson, E.M. Synthesis and Performance of 6FDA-Based Polyimide-Ionenes and Composites with Ionic Liquids as Gas Separation Membranes. Membranes 2019, 9, 79. [CrossRef]

70. O'Harra, K.E.; Kammakakam, I.; Noll, D.M.; Turflinger, E.M.; Dennis, G.P.; Jackson, E.M.; Bara, J.E. Synthesis and Performance of Aromatic Polyamide Ionenes as Gas Separation Membranes. Membranes 2020, 10, 51. [CrossRef]

71. Hall, L.M.; Seitz, M.E.; Winey, K.I.; Opper, K.L.; Wagener, K.B.; Stevens, M.J.; Frischknecht, A.L. Ionic aggregate structure in ionomer melts: Effect of molecular architecture on aggregates and the ionomer peak. J. Am. Chem. Soc. 2012, 134, 574-587. [CrossRef]

72. Evans, C.M.; Bridges, C.R.; Sanoja, G.E.; Bartels, J.; Segalman, R.A. Role of Tethered Ion Placement on Polymerized Ionic Liquid Structure and Conductivity: Pendant versus Backbone Charge Placement. ACS Macro Lett. 2016, 5, 925-930. [CrossRef]

73. Li, P.; Coleman, M.R. Synthesis of room temperature ionic liquids based random copolyimides for gas separation applications. Eur. Polym. J. 2013, 49, 482-491. [CrossRef]

74. Pascault, J.-P.; Williams, R.J.J. Epoxy Polymers: New Materials and Innovations; Wiley-VCH Verlag GmbH: Weinheim, Germany, 2010; ISBN 9781282472297.

75. Sinturel, C.; Thomas, R.; Thomas, S. Micro- and Nanostructured Epoxy/Rubber Blends; Wiley-VCH: Weinheim, Germany, 2014; ISBN 3527666877.

76. White, J.E.; Brennan, D.J.; Silvis, H.C.; Mang, M.N. Epoxy-Based Thermoplastics: New Polymers with Unusual Property Profiles. In Specialty Monomers and Polymers; Havelka, K.O., McCormick, C.L., Eds.; American Chemical Society: Washington, DC, USA, 2000; pp. 132-146. ISBN 0-8412-3637-2.

77. Parajó, J.J.; López, M.V.; Salgado, J. Short-term thermal stability of ionic liquids. In Proceedings of the 21st International Electronic Conference on Synthetic Organic Chemistry, Online. 1-30 November 2017; p. 4820.

78. Chardin, C.; Rouden, J.; Livi, S.; Baudoux, J. Dimethyldioxirane (DMDO) as a valuable oxidant for the synthesis of polyfunctional aromatic imidazolium monomers bearing epoxides. Green Chem. 2017, 19, 5054-5059. [CrossRef]

79. Grugel, R.N.; Kaukler, W.F.; Paley, M.S.; Henry, C.R.; Canaday, C.T.; Hastings, W.C.; Rabenberg, E. Development of Ionic Liquid Based Epoxies for Carbon Fiber Composite Cryogenic Tanks: National Space \& Missile Materials Symposium (NSMMS), Huntsville. 2014. Available online: https: / / ntrs.nasa.gov / search.jsp?R=20140011777 (accessed on 28 February 2020).

80. Syakur, A.; Sutanto, H. Determination of Hydrophobic Contact Angle of Epoxy Resin Compound Silicon Rubber and Silica. IOP Conf. Ser. Mater. Sci. Eng. 2017, 190, 12025. [CrossRef]

81. Paley, M.S.; Libb, R.S.; Grugel, R.N.; Boothe, R.E. Ionic Liquid Epoxy Resins. U.S. Patent US8193280B2, 4 July 2008.

82. Demberelnyamba, D.; Yoon, S.J.; Lee, H. New Epoxide Molten Salts: Key Intermediates for Designing Novel Ionic Liquids. Chem. Lett. 2004, 33, 560-561. [CrossRef]

83. Aslanov, A.F.; Korotkikh, N.I.; Shvaika, O.P. Synthesis of 1,3-diglycidylimidazolium salts. Chem. Heterocycl. Compd. 1996, 32, 914-917. [CrossRef]

84. Lees, I.; Biyani, K.; Connor, E.; Hecker, S.; Zhang, H.; Cope, M.J.; Goka, E.; Lee, A.; Madsen, D.; Shao, J.; et al. Polyimidazoles for Use as Bile Acid Sequestrants. U.S. Patent US20190169342A1, 6 June 2019.

85. Xu, C.; Yuan, L.; Liang, G.; Gu, A. Building a poly(epoxy propylimidazolium ionic liquid)/graphene hybrid through $\pi$ cation $-\pi$ interaction for fabricating high-k polymer composites with low dielectric loss and percolation threshold. J. Mater. Chem. C 2016, 4 , 3175-3184. [CrossRef]

86. Radchenko, A.V.; Duchet-Rumeau, J.; Gérard, J.-F.; Baudoux, J.; Livi, S. Cycloaliphatic epoxidized ionic liquids as new versatile monomers for the development of shape memory PIL networks by 3D printing. Polym. Chem. 2020, 11, 5475-5483. [CrossRef]

87. Rabenberg, E.; Brown, A.; Kaukler, W.F.; Grugel, R.N. Evaluation of an ionic liquid-based epoxy after exposure on the MISSE-8 Carrier. Results Phys. 2016, 6, 1185-1187. [CrossRef]

88. Lyne, C.T.; Henry, C.R.; Kaukler, W.F.; Grugel, R.N. Evaluation of ionic liquid epoxy carbon fiber composites in a cryogenic environment. Results Phys. 2018, 8, 513-515. [CrossRef]

89. Karr, L.; Curreri, P.; Paley, M.; Kaukler, W.; Marone, M. Task-Specific Ionic Liquids for Mars Exploration (Green Chemistry for a Red Planet). LPI Contrib 2012, 4383. Available online: https://www.lpi.usra.edu/meetings/marsconcepts2012/pdf/4383.pdf (accessed on 3 March 2020). 
90. Maksym, P.; Tarnacka, M.; Dzienia, A.; Matuszek, K.; Chrobok, A.; Kaminski, K.; Paluch, M. Enhanced Polymerization Rate and Conductivity of Ionic Liquid-Based Epoxy Resin. Macromolecules 2017, 50, 3262-3272. [CrossRef]

91. Perchacz, M.; Matějka, L.; Konefał, R.; Seixas, L.; Livi, S.; Baudoux, J.; Beneš, H.; Donato, R.K. Self-Catalyzed Coupling between Brønsted-Acidic Imidazolium Salts and Epoxy-Based Materials: A Theoretical/Experimental Study. ACS Sustain. Chem. Eng. 2019, 7, 19050-19061. [CrossRef]

92. Yin, J.; Zhang, C.; Yu, Y.; Hao, T.; Wang, H.; Ding, X.; Meng, J. Tuning the microstructure of crosslinked Poly(ionic liquid) membranes and gels via a multicomponent reaction for improved $\mathrm{CO}_{2}$ capture performance. J. Membr. Sci. 2020, 593,117405 . [CrossRef]

93. Jiang, Z.; Wang, Q.; Liu, L.; Zhang, Y.; Du, F.; Pang, A. Dual-Functionalized Imidazolium Ionic Liquids as Curing Agents for Epoxy Resins. Ind. Eng. Chem. Res. 2020, 59, 3024-3034. [CrossRef]

94. Zhang, C.; Cao, B.; Coleman, M.R.; Li, P. Gas transport properties in (6FDA-RTIL)-(6FDA-MDA) block copolyimides. J. Appl. Polym. Sci. 2016, 133. [CrossRef]

95. Li, P.; Zhao, Q.; Anderson, J.L.; Varanasi, S.; Coleman, M.R. Synthesis of copolyimides based on room temperature ionic liquid diamines. J. Polym. Sci. Part A Polym. Chem. 2010, 48, 4036-4046. [CrossRef]

96. Demir, B.; Perli, G.; Chan, K.-Y.; Duchet-Rumeau, J.; Livi, S. Molecular-Level Investigation of Cycloaliphatic Epoxidised Ionic Liquids as a New Generation of Monomers for Versatile Poly(Ionic Liquids). Polymers 2021, 13, 1512. [CrossRef]

97. Kiefer, J.; Fries, J.; Leipertz, A. Experimental vibrational study of imidazolium-based ionic liquids: Raman and infrared spectra of 1-ethyl-3-methylimidazolium bis(trifluoromethylsulfonyl)imide and 1-ethyl-3-methylimidazolium ethylsulfate. Appl. Spectrosc. 2007, 61, 1306-1311. [CrossRef] [PubMed]

98. Boumediene, M.; Haddad, B.; Paolone, A.; Drai, M.; Villemin, D.; Rahmouni, M.; Bresson, S.; Abbas, O. Synthesis, thermal stability, vibrational spectra and conformational studies of novel dicationic meta-xylyl linked bis-1-methylimidazolium ionic liquids. Journal of Molecular Structure 2019, 1186, 68-79. [CrossRef]

99. ISO/DIS6721-4. Plastics—Determination of Dynamic Mechanical Properties_Part 4: Tensile Vibration-Non-Resonance Method; International Organization for Standardization: Geneva, Switzerland, 2019.

100. ISO/DIS11357-2 Plastics_Differential Scanning Calorimetry (DSC)—Part 2: Determination of Glass Transition Temperature and Step Height; International Organization for Standardization: Geneva, Switzerland, 2014.

101. Burrell, A.K.; del Sesto, R.E.; Baker, S.N.; McCleskey, T.M.; Baker, G.A. The large scale synthesis of pure imidazolium and pyrrolidinium ionic liquids. Green Chem. 2007, 9, 449. [CrossRef]

102. De Nograro, F.F.; Guerrero, P.; Corcuera, M.A.; Mondragon, I. Effects of chemical structure of hardener on curing evolution and on the dynamic mechanical behavior of epoxy resins. J. Appl. Polym. Sci. 1995, 56, 177-192. [CrossRef]

103. Ozeren Ozgul, E.; Ozkul, M.H. Effects of epoxy, hardener, and diluent types on the workability of epoxy mixtures. Constr. Build. Mater. 2018, 158, 369-377. [CrossRef]

104. Cole, K.C.; Hechler, J.J.; Noel, D. A new approach to modeling the cure kinetics of epoxy/amine thermosetting resins. 2 Application to a typical system based on bis[4-(diglycidylamino)phenyl]methane and bis(4-aminophenyl) sulfone. Macromolecules 1991, 24, 3098-3110. [CrossRef]

105. Anusic, A.; Resch-Fauster, K.; Mahendran, A.R.; Wuzella, G. Anhydride Cured Bio-Based Epoxy Resin: Effect of Moisture on Thermal and Mechanical Properties. Macromol. Mater. Eng. 2019, 304, 1900031. [CrossRef]

106. Galy, J.; Sabra, A.; Pascault, J.-P. Characterization of epoxy thermosetting systems by differential scanning calorimetry. Polym. Eng. Sci. 1986, 26, 1514-1523. [CrossRef]

107. Mounif, E.; Bellenger, V.; Mazabraud, P.; Nony, F.; Tcharkhtchi, A. Chemorheological study of DGEBA/IPD system for reactive rotational molding (RRM). J. Appl. Polym. Sci. 2010, 116, 969-976. [CrossRef]

108. Su, C.C.; Woo, E.M. Diffusion-controlled reaction mechanisms during cure in polycarbonate-modified epoxy networks. J. Polym. Sci. Part B Polym. Phys. 1997, 35, 2141-2150. [CrossRef]

109. Garcia, F.G.; Soares, B.G.; Pita, V.J.R.R.; Sánchez, R.; Rieumont, J. Mechanical properties of epoxy networks based on DGEBA and aliphatic amines. J. Appl. Polym. Sci. 2007, 106, 2047-2055. [CrossRef]

110. Boey, F.Y.C.; Qiang, W. Glass-transition temperature-conversion relationship for an epoxy-hexahydro-4-methylphthalic anhydride system. J. Appl. Polym. Sci. 2000, 78, 511-516. [CrossRef]

111. Ignatenko, V.Y.; Ilyin, S.O.; Kostyuk, A.V.; Bondarenko, G.N.; Antonov, S.V. Acceleration of epoxy resin curing by using a combination of aliphatic and aromatic amines. Polym. Bull. 2020, 77, 1519-1540. [CrossRef]

112. Cao, Y.; Mu, T. Comprehensive Investigation on the Thermal Stability of 66 Ionic Liquids by Thermogravimetric Analysis. Ind. Eng. Chem. Res. 2014, 53, 8651-8664. [CrossRef]

113. Krevelen, D.W. Properties of Polymers: Their Correlation with Chemical Structure; Their Numerical Estimation and Prediction from Additive Group Contributions, 4th ed.; Elsevier Science \& Technology: Oxford, UK, 2009; ISBN 978-0-08-054819-7.

114. Qian, W.; Texter, J.; Yan, F. Frontiers in poly(ionic liquid)s: Syntheses and applications. Chem. Soc. Rev. 2017, 46, 1124-1159. [CrossRef] 